\title{
Recent changes in climate, hydrology and sediment load in the Wadi Abd, Algeria (1970-2010)
}

\author{
Mohammed Achite ${ }^{1}$ and Sylvain Ouillon ${ }^{2,3}$ \\ ${ }^{1}$ Laboratoire Eau-Environnement, Université Hassiba Ben Bouali, BP 151, Hay Es-Salem, Chlef, Algeria \\ ${ }^{2}$ LEGOS, Université de Toulouse, IRD, CNRS, CNES, UPS, 14 avenue E. Belin, 31400 Toulouse, France \\ ${ }^{3}$ University of Science and Technology of Hanoi, Dept. Water-Environment-Oceanography, 18 Hoang Quoc Viet, \\ Cau Giay, Hanoi, Vietnam \\ Correspondence to: Sylvain Ouillon (sylvain.ouillon@ird.fr)
}

Received: 20 September 2015 - Published in Hydrol. Earth Syst. Sci. Discuss.: 14 October 2015

Revised: 7 March 2016 - Accepted: 19 March 2016 - Published: 6 April 2016

\begin{abstract}
Here we investigate the changes of temperature, precipitation, river runoff and sediment transport in the Wadi Abd in northwest Algeria over a time series of 40 hydrological years (1970-2010). Temperature increased and precipitation decreased with the reduction in rainfall being relatively higher during the rainy season. A shift towards an earlier onset of first rains during summer was also found with cascading effects on hydrology (hydrological regimes, vegetation, etc.) and thus on erosion and sediment yield. During the 1980s, the flow regime shifted from perennial to intermittent with an amplification of the variations of discharge and a modification of the sediment regime with higher and more irregular suspended particulate flux. Sediment flux was shown to almost double every decade from the 1970s to the 2000s. The sediment regime shifted from two equivalent seasons of sediment yield (spring and fall) to a single major season regime. In the 2000s, autumn produced over 4 times more sediment than spring. The enhanced scatter of the $C-$ $Q$ pairs denotes an increase of hysteresis phenomena in the Wadi Abd that is probably related to the change in the hydrologic regime. At the end of the period, due to irregularity of the discharge, the ability of a rating curve to derive suspended sediment concentration from river discharge was poor.
\end{abstract}

\section{Introduction}

Fluvial and estuarine suspended sediment fluxes are changing dramatically under the combined effects of anthropogenic activities and climate change. On a global scale, re- cent changes showed a trend towards increasing land erosion and decreasing fluxes to coastal waters (Walling and Fang, 2003; Vörösmarty et al., 2003; Wang et al., 2006). The sediment flux trapped in regulated basins with reservoirs is higher than $50 \%$ (Vörösmarty et al., 2003). Locally, it can reach more than $60 \%$ after the impoundment of one single dam, like on the Red River (Vinh et al., 2014), and more than $80 \%$ on rivers with many dams ( $86 \%$ on the Yellow River, Wang et al., 2007; > $95 \%$ on the Ebro River, Durand et al., 2002). Other engineering activities (meander cutoffs, river-training structures, bank revetments, soil erosion controls) also significantly affect sediment fluxes and can participate in the shift from a transport-limited system to a supply-limited system, like on the Missouri-Mississipi River system (Meade and Moody, 2010).

Climate change, through increasing temperatures and evaporation, tends to accelerate the water cycle and modify hydrologic regimes (Bates et al., 2008). Precipitation intensities and the frequency of extreme events are projected to increase under climate change, leading to more frequent flood events of higher magnitude that will, in turn, affect patterns of erosion and deposition within river basins (Tucker and Slingerland, 1997; Pruski and Nearing, 2002; Tockner and Stanford, 2002; Coulthard et al., 2012). Recent studies focused on the impact of climate change on sediment transport (e.g. Gomez et al., 2009; Hancock, 2009; Walling, 2009; Hancock and Coulthard, 2011; Knight and Harrison, 2013; Lu et al., 2013). Syvitski (2003) showed on an example that sediment transport may increase due to the increasing discharge or decrease because of the enhanced tempera- 
ture. Studies have compared trends in hydrological and sediment time series to land use changes (Wang et al., 2007; Memariam et al., 2012; Gao et al., 2012). Climate projections are consistent regarding warming and the acceleration of the water cycle (IPCC, 2013), however, they remain to be defined on sediment transport where projections show a high uncertainty (Shrestha et al., 2013; Lu et al., 2013). This is in part due to the fact that climate affects many factors controlling sediment yield, such as surface moisture availability, weathering processes and rates, and the nature of riparian vegetation (Nanson et al., 2002).

While sediment transport is well documented in perennial rivers in humid or temperate climates, its study in semiarid areas is still fragmentary due to the difficulty of sampling during flashfloods. Amongst the factors favouring erosion (slope, nature of rocks, relief, climate, human activities), climate is recognized to be the main factor in semi-arid Mediterranean areas of Algeria which experience short and intense rain episodes, high evaporating power of wind, prolonged droughts and freezing and thawing cycles (Touaibia, 2010; Houyou et al., 2014). Erosion is extremely active and the average concentration is at least 1 order of magnitude higher than the global average (Achite and Ouillon, 2007). One of the main impacts of this high erosion is the rapid silting up of reservoirs (up to $2-5 \%$ per year, Kassoul et al., 1997; Remini et al., 2009; Touaibia, 2010) with important consequences on water resource management in a region where $85 \%$ of rain evaporates (Benhamiche et al., 2014). The high temporal variability and recent changes in forcings mean that it is necessary to study sediment dynamics in such environments over time periods of several decades in order to document and understand the changes in sediment regime.

Achite and Ouillon (2007 hereafter referred as AO2007) analysed sediment transport changes in the Wadi Abd, an Algerian wadi over a 22-year period (1973-1995). Here we extend this analysis of sediment transport changes to cover a 40-year period (1970-2010). The hydrologic gauging station is located upstream from a dam and is not affected by any major management. This river sub-basin is also particularly suitable for such study because its hydrologic regime was shown to have drastically changed between the 1970s and the 1980s. Precipitation decreased and became more irregular and the flow regime shifted from perennial to intermittent with $26 \%$ dry days, on average, in 1990-1995. Variations of discharge were amplified, and a modified sediment regime occurred with a higher and more irregular suspended particulate flux, that was 4.7 times higher over the period 1985-1995 than over 1973-1985. AO2007, showing the advantage of working with over 22 years of measurement, however, stressed the difficulty of defining a reference period, and the need to extend the study over a longer period of time. The objectives of this additional study are to (1) describe precipitation, discharge and sediment flux variability of the Wadi Abd basin over a 40-year period; (2) detect the shift, if any, in temperature, runoff and sediment yield; (3) determine the relation- ship between sediment load and runoff over the last 40 years; (4) detect when a shift occurred in the runoff-sediment load relationship; (5) analyse the possible causes of the change in flow regime and its consequences on suspended sediment discharge; and (6) assess the use of rating curves and the physical signification of their parameters when a river is experiencing a transition and shifts from a perennial regime to an intermittent regime.

\section{Study area: the Wadi Abd}

\subsection{General information}

The Wadi Abd, located in northwest Algeria, is a tributary of the Wadi Cheliff, the principal river of Algeria (Fig. 1). The length of the Wadi Abd's main stream is $118 \mathrm{~km}$, the basin area is $2480 \mathrm{~km}^{2}$ and the drainage density is $3.70 \mathrm{~km} \mathrm{~km}^{-2}$ (Fig. 2a). The Wadi Abd supplies the downstream Sidi Mohamed Benaouda (SMB) reservoir which has a basin area of $4900 \mathrm{~km}^{2}$. The Wadi Abd catchment area is formed of erodible sedimentary rocks from the Upper Jurassic (45.9\% of its surface), Middle Jurassic (20.2\%) and Pliocene (7.4\%) (Fig. 2b). Soft bottom sedimentary deposits from the Quaternary cover $13 \%$ of the basin along the wadi (Tecsult International, 2004).

The climate is Mediterranean and is characterized by a dry season from April to August/September, and a wet season from September to March. The hydraulic deficit is very high. Annual precipitation is $264 \mathrm{~mm}$, on average, while the mean potential evapotranspiration over the SMB basin is $1525 \mathrm{~mm}$ (Tecsult International, 2004).

The watershed mainly consists of steep slopes (Fig. 2c) with very sparse vegetation or bare soil (Fig. 2d). The main land use is natural environment $(73 \% ; 17 \%$ of forests $+56 \%$ of scrub and bare steppe soils), cultivated lands cover about $26 \%$ and cities $0.4 \%$. Seven hill reservoirs were built in the Wadi Abd basin from 1986 to 2004 for agriculture (irrigation and livestock watering) or for fire-fighting measures. Their total cumulated capacity is $0.88 \mathrm{hm}^{3}$, representing $2.3 \%$ of the yearly averaged discharge at Ain Hamara station. These small reservoirs are now silted up to $70 \%$ of their volume.

In 2008, 123000 inhabitants were living in the Wadi Abd basin (average density: 49 inhabitants $\mathrm{km}^{-2}$ ), $44 \%$ of them living in the city of Takhmaret. The Wadi Abd is thus little influenced by human activities, in view of its extensive surface that is subject to severe natural erosion.

In the plain, sheet (interrill) and rill erosion dominates (Fig. $3 b$ and f). Gully erosion is mainly restricted to the mountainous regions of Frenda and Tiaret in the north (Figs. 3c, d and 2c), while some mid-slope areas are gullying (Fig. 3a and e). 


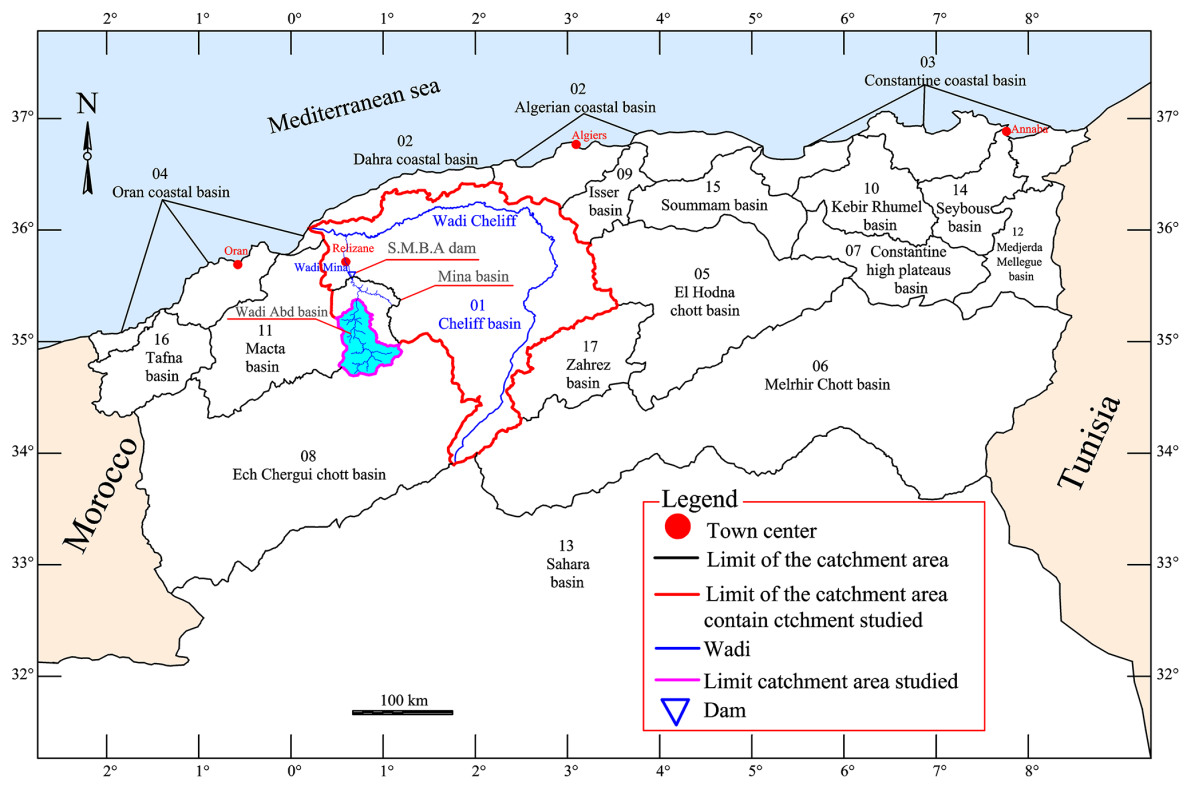

Figure 1. Location of the Wadi Abd sub-basin within the Mina and Cheliff basins, and the other main basins of Algeria.
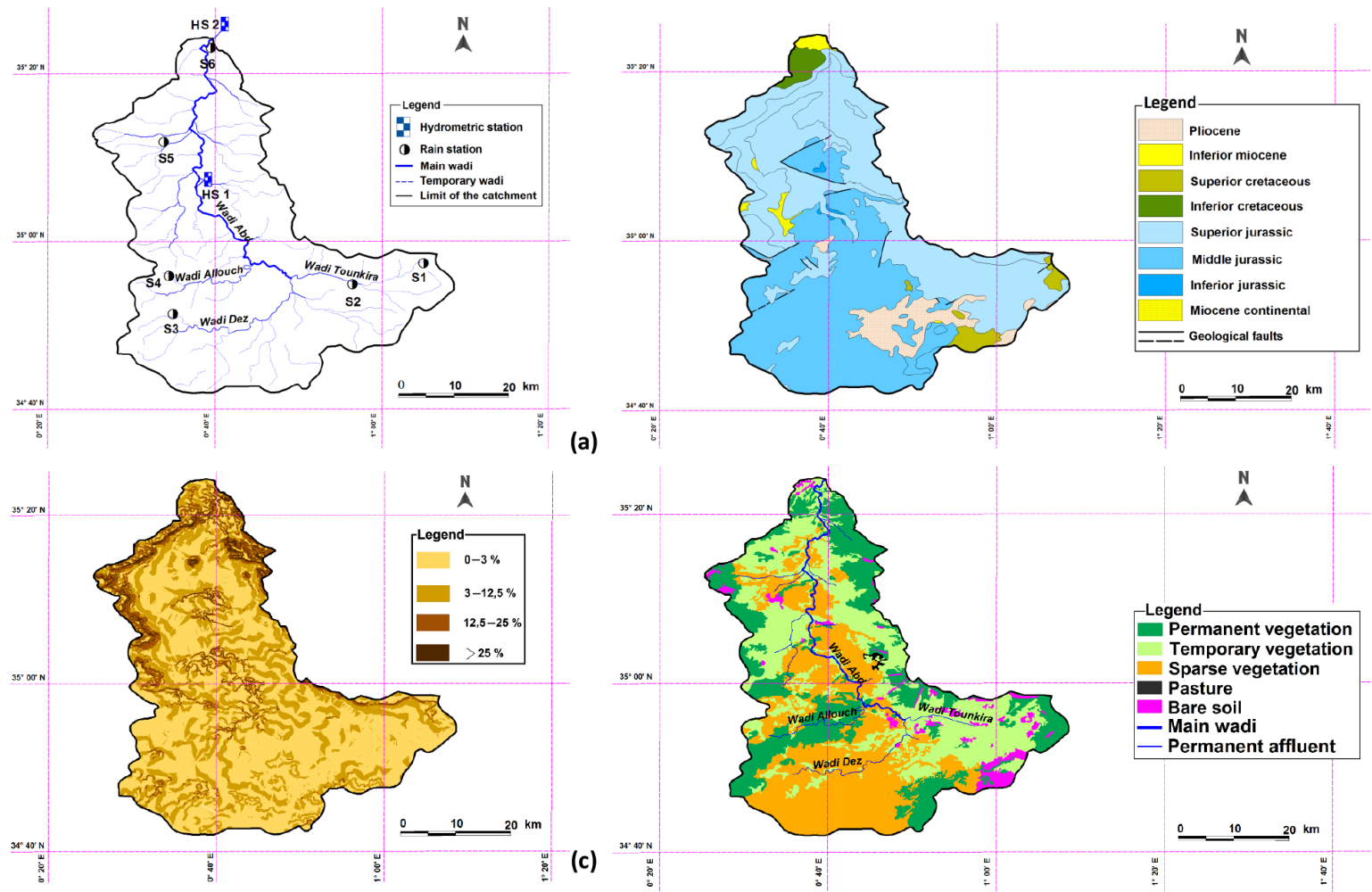

(a)

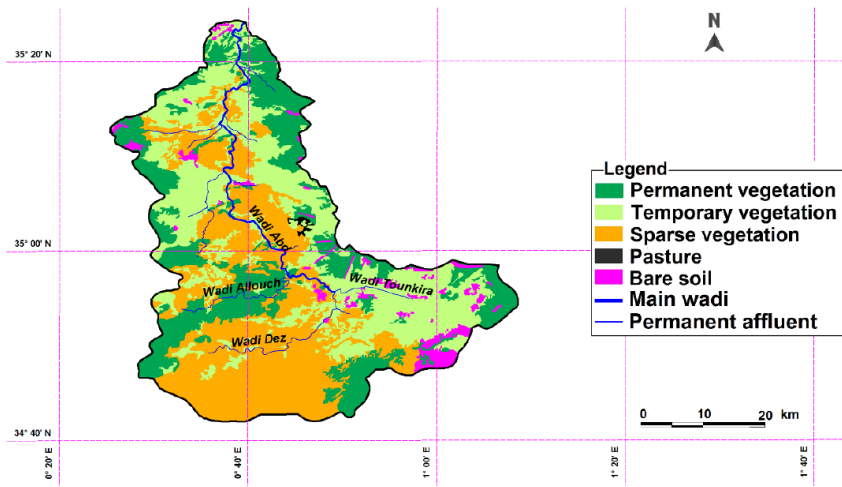

(b)

(c)

Figure 2. The Wadi Abd catchment area. (a) displays rain and hydrometric stations including HS1 at Takhmaret and HS2 at Ain Hamara, (b) geology, (c) slopes from the digital elevation model of north Algeria, (d) vegetation cover from Landsat ETM+ data of 2009.

\subsection{Data}

Long-term series of temperature measured at three stations in Algeria were extracted from CRUTEM4 (Jones et al.,
2012; Osborn and Jones, 2014). These stations are located at Chlef $\left(36.20^{\circ} \mathrm{N}, 1.30^{\circ} \mathrm{E}-1951-2011\right)$, Miliana $\left(36.30^{\circ} \mathrm{N}\right.$, $\left.2.20^{\circ} \mathrm{E}-1922-2011\right)$ and Dar El Beida $\left(36.70^{\circ} \mathrm{N}, 3.30^{\circ} \mathrm{E}\right.$ - 1856-2011). Annual average temperatures were calculated 


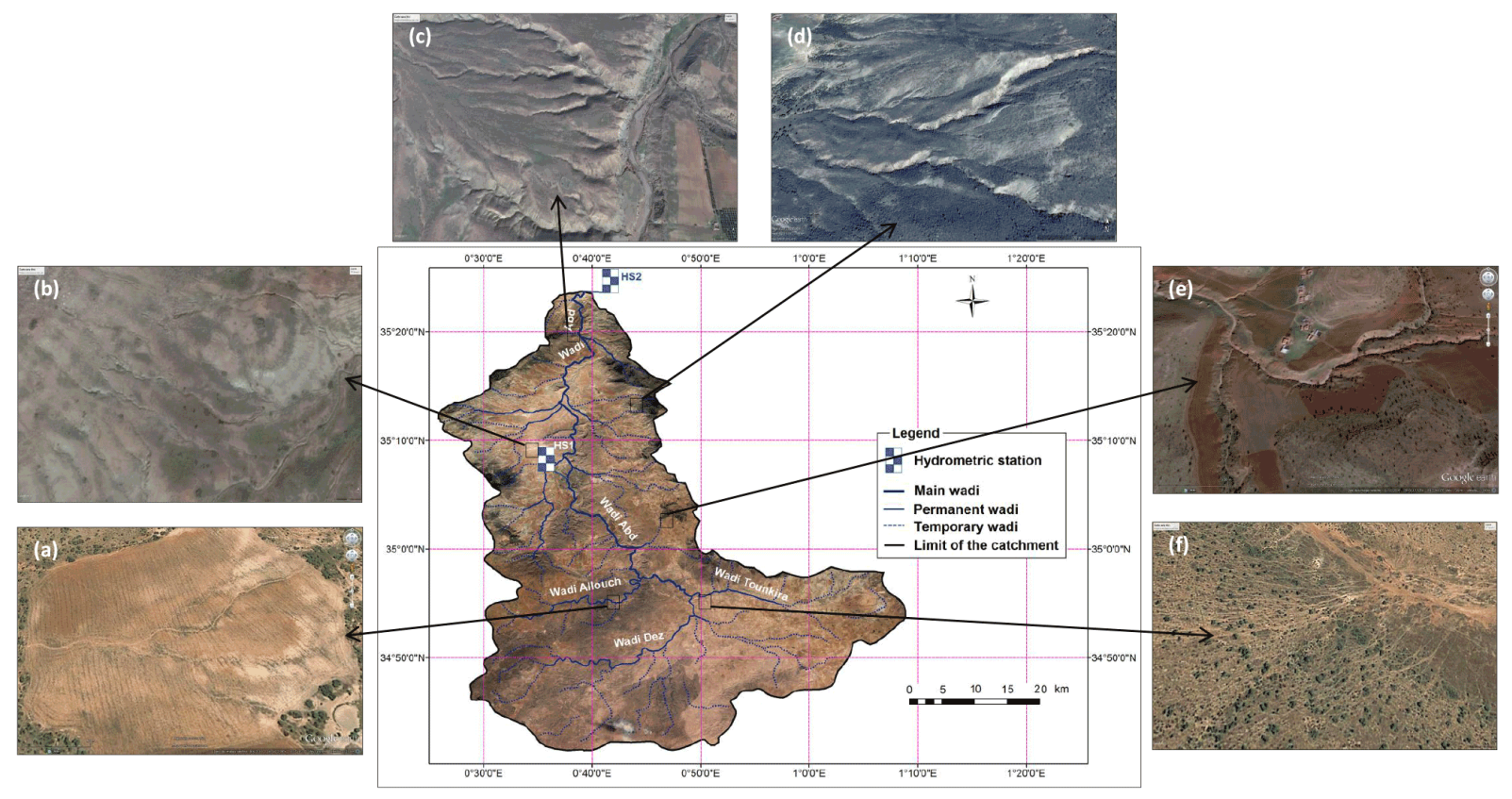

Figure 3. Linear erosion forms in the Wadi Abd basin. (a) and (e) display gullying (depth: 30-50 cm, width > $1 \mathrm{~m}$ ), (c) and (d) gully erosion (depth: 50-200 cm), (b) and (f) interill and rill erosion.

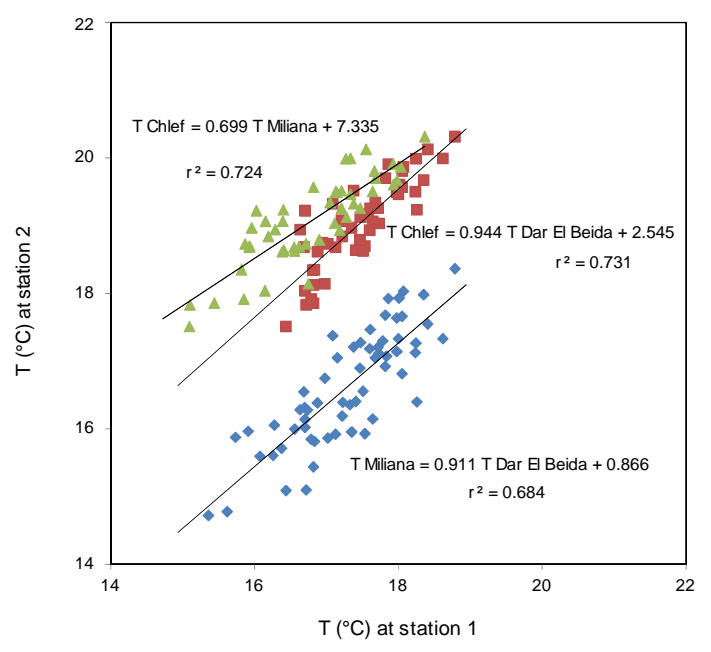

Figure 4. Relationships between mean annual temperatures at the three stations of Dar El Beida, Miliana and Chlef (from CRUTEM4).

for each station from the 12 monthly averages. The 20 missing monthly data (out of 480) at Chlef, the nearest station from the Wadi Abd, were extrapolated from the monthly temperatures measured at Miliana and Dar El Beida using the relationships between the monthly average temperatures at Chlef and Miliana, and Chlef and Dar El Beida (Fig. 4). The resulting estimates of temperature at Chlef on seasonal and yearly scales allowed us to estimate changes by decade over the period 1970-2010.
Rainfall and hydrometric records were provided by the National Agency of Hydraulic Resources (ANRH). Time series of rainfall data are available at six stations within the basin (see Fig. 2a): S1 Ain Kermes (altitude: $1162 \mathrm{~m}$ ), S2 Rosfa $(960 \mathrm{~m})$, S3 Sidi Youcef $(1100 \mathrm{~m})$, S4 Tiricine $(1070 \mathrm{~m})$, S5 Takhmaret $(655 \mathrm{~m})$ and S6 Ain Hamara $(288 \mathrm{~m})$. There were 9076 coincident instantaneous measurements of water discharge (namely $Q$, in $\mathrm{m}^{3} \mathrm{~s}^{-1}$ ) and suspended sediment concentrations $\left(C\right.$, in $\left.\mathrm{g} \mathrm{L}^{-1}\right)$ recorded at the Ain Hamara gauging station between September 1970 and August 2010. Water depths were measured continuously and a calibration between water level and discharge was regularly performed from velocity profiles. During flow measurements, water was manually sampled once or twice using a $1 \mathrm{~L}$ dip at the edge of the wadi. The number of samples was adapted to the flow regime. During baseflow samples were collected every other day, whereas during floods samples were collected at higher rates (up to one every $30 \mathrm{~min}$ ). Water samples were filtered on preweighed Whatman glass fiber filters (GFF), oven dried at $105^{\circ} \mathrm{C}$ for $24 \mathrm{~h}$, and weighed again to determine the concentration. This method, used by ANRH at all hydrologic stations in Algeria, underestimates the suspended load as compared to its value averaged over the cross section under low turbulence (i.e. at low flow) since water is sampling near the surface (Touat, 1989). During floods, which transport most of the sediment load, turbulence is high enough to homogenize suspension load. While this underestimation may slightly affect the budget, it does not severely affect the time variability of suspended matter which is analysed in this paper. From 9076 coincident instantaneous data 
measured during 1213 days, average arithmetic values were calculated per day so as to obtain 1213 pairs of "mean daily" $(C, Q)$ values. The resulting "mean daily $Q$ " differs from the (true) daily discharge obtained from the averaging of $24 \mathrm{~h}$ of continuous instant $Q$.

The Atlantic Multidecadal Oscillation (AMO) index is an index of North Atlantic temperatures. The monthly unsmoothed values used in this study were calculated by NOAA, Earth System Research Laboratory, Physical Sciences Division/ESRL/PSD1 (http://www.esrl.noaa.gov/psd/ data/timeseries/AMO/).

\section{Models and methods}

\subsection{Trends}

The analysis of trends was conducted following a method fully described by Stahl et al. (2010) and Déry et al. (2005) for river runoff. The Kendall-Theil robust line furnishes a linear equation from a time series of $n$ measurements such as

$y=m t+b$

where $t$ is time (year), $y$ denotes the hydrological parameter (precipitation, river discharge and sediment discharge) and $m$ is the magnitude of the trend over this period. $m$ is calculated as the median of all slopes $m_{k}$ of consecutive pairs of values:

$m_{k}=\frac{y_{j}-y_{i}}{t_{j}-t_{i}}$,

where $k=[1, n(n-1) / 2], i=[1, n-1], j=[2, n]$. This slope is often referred to as the Sen slope (Sen, 1968). The significance of this trend at a level $p$ was calculated following Ziegler et al. (2003).

\subsection{Rating curves}

$C$ and $Q$ measurements were used to define rating curves that estimate $C$ from measured values of $Q$, according to a common approach (e.g. Walling, 1977a; Asselman, 2000; El Mahi et al., 2012; Tebbi et al., 2012; Louamri et al., 2013). The most suitable model is a power law of the type $C=a Q^{b}$ for which the coefficients $(a, b)$ determined empirically account for the effectiveness of erosion and transport. The rating curve established from the 1213 daily averages of $C$ and $Q$ data enabled the estimation of $C$ then $Q_{\mathrm{s}}\left(Q_{\mathrm{s}}=C \times Q\right)$ for the whole period 1970-2010 from the measured daily $Q$ values.

Considering the change in hydrologic regime during the study period, we wondered if the estimate of $C$ and $Q_{\text {s }}$ per subperiods such as decades would be more appropriate. We therefore applied the four rating curves established for the 4 decades to the time series of daily $Q$ to obtain daily $C$ and then daily $Q_{\mathrm{s}}$. This method (B) enabled us to compare the estimated solid discharge with the value provided

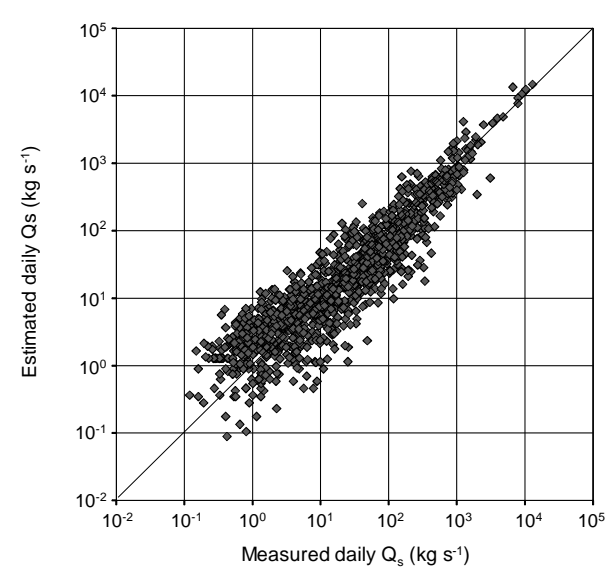

Figure 5. Comparison between estimates of $Q_{\mathrm{s}}$ obtained from $Q$ and the global rating curve, and measured $Q_{\mathrm{s}}$.

by the global relationship established from 40 years of data (method A). The average error for daily $Q_{\mathrm{s}}$ values was $51 \%$ using method $\mathrm{A}$ and $42.1 \%$ using method $\mathrm{B}$. However, the cumulative flux of suspended matter over the 1213 days for which daily data are available was overestimated by $3.1 \%$ using method $A$ while it was underestimated by $5 \%$ using method B. A comparison of the estimates by these two methods showed that method B is not reliable at high discharge during the last decade because of an increase in scattering of the $C, Q$ pairs. The relationship obtained over the last decade (2000-2010) led to an underestimation of $Q_{\mathrm{s}}$ of $23 \%$ over the 314 days for which daily $C$ and $Q$ are known. In contrast, the global algorithm from method A led to an underestimation of the same cumulated $Q_{\mathrm{s}}$ by only $3.5 \%$ over the same period. The relationship established over 40 years was therefore used for this study.

It should be noted that although method A provides some daily solid discharges from the 1213 daily $Q$ values with a high error (the average error being $51 \%$ ), it enabled the reconstruction of good trends of $Q_{\mathrm{s}}$ values over more than 7 orders of magnitude (Fig. 5). The temporal variability of the coefficients $a$ and $b$ of the rating curves calculated over years or decades will be discussed in light of the variability of the forcings and their consequences on sediment transport in order to better understand their physical meaning.

\subsection{Average loads}

In order to analyse the temporal variability of suspended sediment flux, we use the average concentration resulting from the ratio between the solid and the liquid flow rate, denoted as $\mathrm{SPM}^{*}$, which can be defined for any integration period (day, month, season, year). 


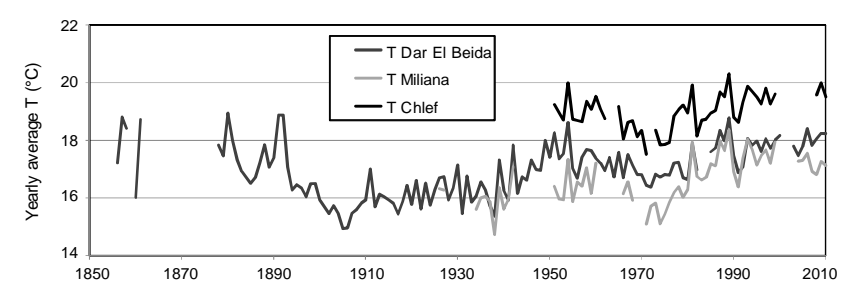

Figure 6. Interannual variations of mean yearly temperature (calculated from September to August monthly temperatures) at three stations in northern Algeria: Dar El Beida, Miliana and Chlef (from measurements of CRUTEM4 only, extrapolated values are not shown).

\subsection{Study of breaks: double-mass curve}

Double-mass curves were used to determine long-term trends and changes in the hydrosedimentary regime (Searcy and Hardison, 1960; Walling, 1977b, 2006).

\section{Interannual variations of temperature, precipitation, river discharge and flow regime}

The statistics of hydrological parameters at Ain Hamara gauging station over the period 1970-2010 are reported in Table 1 .

\subsection{Temperature}

Temperature in northern Algeria at the three stations of Chlef, Miliana and Dar El Beida increased from the 1970s onwards (Fig. 6), with higher values at Chlef than at Dar El Beida and Miliana. On average, temperature at Chlef increased by $1.17^{\circ} \mathrm{C}$ from the 1970 s to the 2000s (Table 2). The increase was $0.87^{\circ} \mathrm{C}$ between the 1970 s and the $1980 \mathrm{~s}$ which is more than 4 times the difference between the $1980 \mathrm{~s}$ and the $1990 \mathrm{~s}\left(+0.18^{\circ} \mathrm{C}\right)$ and the $1990 \mathrm{~s}$ and the $2000 \mathrm{~s}$ $\left(+0.12{ }^{\circ} \mathrm{C}\right)$. As has been shown on a global scale, the decade of the 2000s was the warmest (IPCC, 2013).

\subsection{Precipitation}

Annual precipitation at Ain Hamara station was highly irregular, varying between 165 and $506 \mathrm{~mm} \mathrm{yr}^{-1}$ (Table 1, Fig. 7). Mean annual precipitation $(P)$ was $264 \mathrm{~mm}$, with a coefficient of variation (CV) of $27 \%$ between 1970-1971 and 2009-2010. The interannual variations of $P$ (Fig. 7) showed trends towards a decrease of rainfall $\left(-1.86 \mathrm{~mm} \mathrm{yr}^{-1}\right.$, on average, over 40 years, $p<0.05$ ). $P$ decreased by $15 \%$ (from 310 to $264 \mathrm{~mm}$ ) between the 1970 s and 2000s (Table 2). A more precise analysis shows that rainfall greatly decreased from the 1970 s to the next decade (from 310 to $231 \mathrm{~mm}$, $-25 \%$ ), then slightly increased in the 2 following decades (see Table 2).
The average precipitation over the six rainfall gauging stations within the basin was $273 \mathrm{~mm} \mathrm{yr}^{-1}$, with consistent variations as compared to the Ain Hamara station. Five out of six stations show a decrease in precipitation between 1970-1985 and 1985-2010, the average deficit being equal to $3.7 \%$.

\subsection{River discharge and flow regime}

The annual discharge was $1.18 \mathrm{~m}^{3} \mathrm{~s}^{-1}$, on average, and exhibited a higher interannual variability $(\mathrm{CV}=44.4 \%)$ than annual precipitation (Table 1). Yearly values showed a trend towards an increase of river flow $\left(+11.3 \mathrm{~L} \mathrm{~s}^{-1} \mathrm{yr}^{-1}\right.$, on average, over 40 years, $p<0.01$; Fig. 7), with decreasing decadal values between the 1970 s and the 1980 s, then increasing values afterwards, similar to $P$ (Table 2).

Detailed analysis of daily river discharge shows that the river was perennial in the 1970 s and then became intermittent during the 1980s (Fig. 8). The driest year occurred in 19931994 with 117 days of the fully dry river. In Fig. 8, very low river discharges (around $0.01 \mathrm{~m}^{3} \mathrm{~s}^{-1}$ ) were not considered as days of dry river.

From the 1970 s to 2000 s, when $Q$ averaged over 10 years increased by $25 \%$, the wet discharge $Q_{\mathrm{w}}$ (i.e. the yearly average discharge of the days of running river) increased by more than $35 \%$ (Table 2). Two indicators of intra-annual discharge variability are shown in Fig. 7: $Q_{98}$, the 98th percentile of annual flows calculated from daily discharge and the standard deviation of daily discharge within each year $\left(\sigma_{Q}\right) . Q_{98}$ increased by a factor 3.2 between 1970-1980 and 2000-2010 (Table 2). $Q_{98}$ is a good indicator of changes in sediment transport as it occurs during the highest flood events that occur each year.

\section{Interannual variation of sediment load}

\subsection{Rating curve}

The rating curve obtained from 1213 pairs of daily averages gave the following:

$C=2.270 Q^{0.647}\left(r^{2}=0.431\right)$.

Of the variations of $C, 43 \%$ are explained by those of $Q$. The rating curve obtained between $Q$ and $Q_{\mathrm{s}}$ shows a much higher coefficient of determination $\left(r^{2}=0.831\right)$ but is biased since $Q_{\mathrm{s}}=C \times Q$. Nevertheless, both relationships give estimates of $Q_{\mathrm{s}}$ values from $Q$ with less than $1 \%$ difference which is less than the uncertainty of $Q_{\mathrm{s}}$.

\subsection{Yearly sediment fluxes and concentrations}

\subsubsection{Decadal variability of $Q_{\mathrm{s}}$}

$Q_{\text {s }}$ increased from 180 to $1130 \times 10^{3}$ t per year between the 1970 s and the 2000s (Table 2). The increase from one decade 
Table 1. General statistics on the yearly averages of hydrologic parameters from the Wadi Abd at Ain Hamara gauging station over the period 1970-2010 (note: $T$ at Chlef was estimated from measurements at Dar El Beida and Miliana for 20 months over 480 months).

\begin{tabular}{lllllll}
\hline Statistic & $\begin{array}{l}T \text { (Chlef) } \\
{ }^{\circ} \mathrm{C}\end{array}$ & $\begin{array}{l}P \\
\mathrm{~mm} \mathrm{yr}^{-1}\end{array}$ & $\begin{array}{l}Q \\
\mathrm{~m}^{3} \mathrm{~s}^{-1}\end{array}$ & $\begin{array}{l}Q_{\mathrm{w}} \\
\mathrm{m}^{3} \mathrm{~s}^{-1}\end{array}$ & $\begin{array}{l}M \\
10^{3} \mathrm{tyr}^{-1}\end{array}$ & $\begin{array}{l}\mathrm{SPM}^{*} \\
\mathrm{~g} \mathrm{~L}^{-1}\end{array}$ \\
\hline Mean & 19.09 & 264 & 1.18 & 1.29 & 564 & 12.3 \\
Min & 17.52 & 165 & 0.37 & 0.46 & 33.1 & 2.56 \\
(Year) & $1971-1972$ & $1999-2000$ & $1992-1993$ & $1983-1984$ & $1992-1993$ & $1975-1976$ \\
Max & 20.32 & 506 & 2.19 & 2.98 & 3266 & 50.25 \\
(Year) & $1989-1990$ & $1995-1996$ & $1994-1995$ & $1994-1995$ & $2007-2008$ & $2007-2008$ \\
SD & 0.69 & 71.2 & 0.52 & 0.59 & 696 & 10.6 \\
CV $(\%)$ & & 27.0 & 44.4 & 45.6 & 123.3 & 86.0 \\
\hline
\end{tabular}

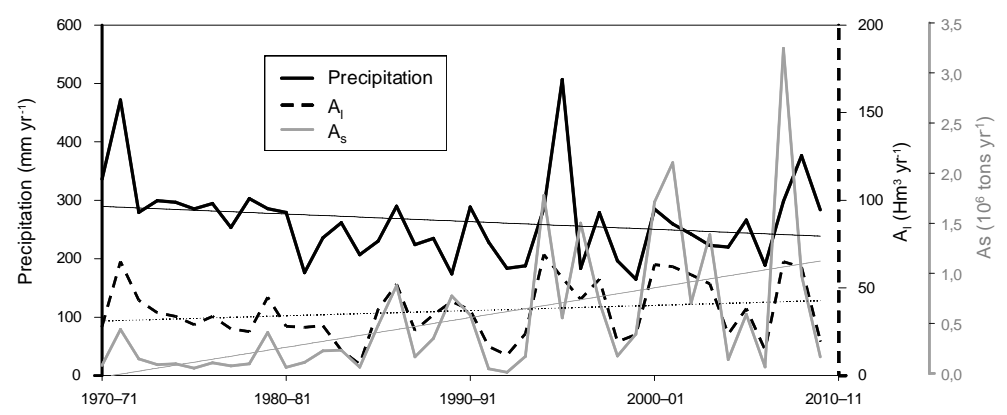

Figure 7. Interannual variations of annual precipitation, water discharge and sediment yield at Ain Hamara station.

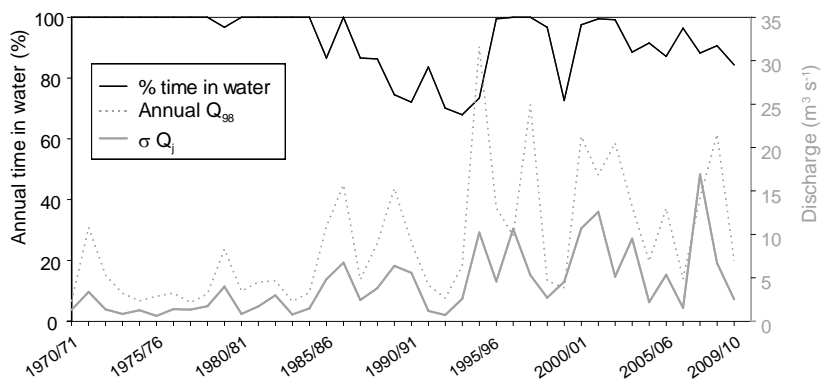

Figure 8. Variation of hydrological regime with annual percentage of time of flowing water, $Q_{98}$ (amongst daily discharges, per year) and annual standard deviation of daily river discharge.

to the next is remarkably regular: $+85 \%$ between the 1970 s and the 1980 s, $+84 \%$ between the 1980 s and the 1990 s, $+84 \%$ between the 1990 s and the 2000 s and is statistically significant $\left(+19.7 \times 10^{3} \mathrm{tyr}^{-1}\right.$, on average, $\left.p<0.05\right)$. Specific sediment yield follows the same trend (Table 2).

\subsubsection{Variability of mean annual load SPM*}

The average value of $\mathrm{SPM}^{*}$ over the period $1970-2010$ is $12.3 \mathrm{~g} \mathrm{~L}^{-1}$, with annual values comprised between 2.5 and $50.2 \mathrm{~g} \mathrm{~L}^{-1}$ (Tables 1 and 2). Their interannual variation was smaller than that of solid discharge because annual $\mathrm{SPM}^{*}$ is the ratio of the annual $Q_{\mathrm{s}}$ to the annual $Q$ (which increased less than $Q_{\mathrm{s}}$ ).

\subsubsection{Analysis of break points}

The double-mass plot enabled us to identify changes in the sediment response of the stream (Fig. 9). A major break occurred in 1985-1986. A secondary break was noticed in 1991-1992, but the entire period 1985-1986/2009-2010 may be considered as a single period (with the relationship "cum $Q_{\mathrm{s}}$ " $=0.021 \times$ "cum $\left.Q "-9.417, r^{2}=0.989\right)$. The period 1985-1986/1991-1992 may thus be considered as a transient event towards a new regime.

The response of sediment flow to various constraints differs clearly from that of discharge from the year 1985-1986 onwards. This break corresponds to the first year of dry river over a long period in summer (49 days). This initiates a phase of intermittent flow regime. The averaged parameters for the two periods 1970-1985 and 1985-2010 were added to the tables, in addition to average values throughout the full study period and values for decades to illustrate the dynamics of the hydrological and hydrosedimentary change.

\subsection{High dependency of the solid discharge on $Q$ variability}

The variability of $Q$ and $Q_{\mathrm{s}}$ or $\mathrm{SPM}^{*}$ at different timescales were compared. AO2007 showed that, over 22 years, $71 \%$ of the variance of the annual SPM* values was accounted for by annual discharge and $73 \%$ by the 95 th percentile of daily discharge within the given year $Q_{95}$. This means that $\mathrm{SPM}^{*}$ was 


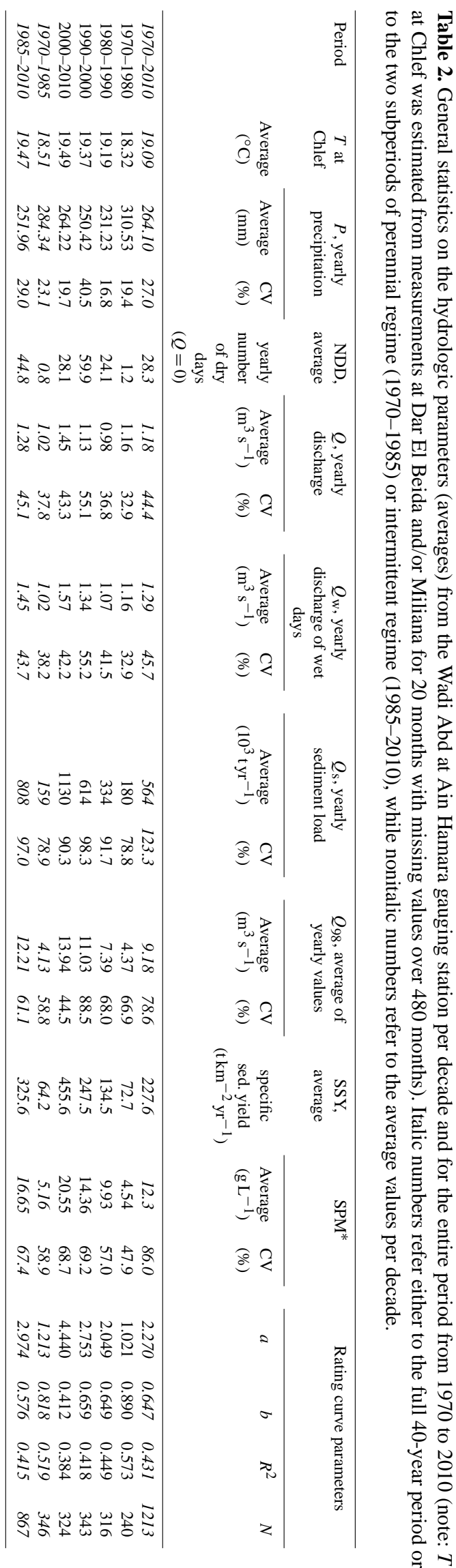



Figure 9. Double-mass plot of sediment yield versus water flow.

mainly driven by the $10-15$ highest daily discharges in a year, suggesting a strong correlation between yearly $Q_{\mathrm{s}}$ and the discharge variability. Finally, they showed a remarkable linearity between $\mathrm{SPM}^{*}$ and the standard deviation of the daily discharge per year $\left(\sigma_{Q}\right)$.

Yearly SPM $^{*}$ and yearly $\sigma_{Q}$ still showed a strong linearity over 40 -year period $\left(r^{2}=0.956\right.$, Fig. 10a). A higher correlation was obtained between yearly $Q_{\mathrm{S}}$ or SSY, the specific sediment yield, and yearly $\sigma_{Q}\left(r^{2}=0.991\right.$, Fig. 10b). In conclusion, for this river, the yearly solid discharge is more closely dependent on the discharge variability than on discharge values.

\section{Variation of the seasonality of climatic and hydrological parameters}

The yearly values of temperature at Chlef generally increased but the monthly averages showed high discrepancies. Temperature from March to November increased with a maximum of increase in June $\left(+3.30^{\circ} \mathrm{C}\right.$, on average, between the 1970s and 2000s), it remained quite constant in December and February and decreased by $0.98^{\circ} \mathrm{C}$ in January over the same period. Considering the average values per season, winter values (December-February) decreased by $0.33^{\circ} \mathrm{C}$ between the 1970s and the 2000s, while spring values (MarchMay) increased by $1.66^{\circ} \mathrm{C}$, summer values (June-August) by $2.22^{\circ} \mathrm{C}$ and fall values (September-November) by $1.29^{\circ} \mathrm{C}$. In summary, annual temperature differences increased with minimum temperatures down slightly and maximum temperatures rising sharply. The increase was most marked in JulyAugust.

Averaged seasonal values of $P, Q$ and $Q_{\mathrm{s}}$ for each decade are given in absolute values and in percent of the yearly values in Table 3. The seasonal relative contribution of $P, Q$ and $Q_{\mathrm{s}}$ centred and averaged over 9 consecutive years are 
Table 3. Variation of precipitation, water discharge and sediment yield averaged per season over each decade.

\begin{tabular}{|c|c|c|c|c|c|c|c|c|c|c|c|c|}
\hline & \multicolumn{4}{|c|}{ Precipitation $(\mathrm{mm})$} & \multicolumn{4}{|c|}{ Water discharge $\left(\mathrm{m}^{3} \mathrm{~s}^{-1}\right)$} & \multicolumn{4}{|c|}{ Sediment yield $\left(10^{3} \mathrm{t}\right)$} \\
\hline & Autumn & Winter & Spring & Summer & Autumn & Winter & Spring & Summer & Autumn & Winter & Spring & Summer \\
\hline 1970-1980 & 68.5 & 102.6 & 128.2 & 11.2 & 1.26 & 1.38 & 1.41 & 0.58 & 62.2 & 43.7 & 66.1 & 8.4 \\
\hline 1980-1990 & 56.0 & 94.4 & 70.7 & 10.1 & 1.15 & 1.29 & 1.08 & 0.40 & 128.8 & 61.0 & 97.2 & 46.8 \\
\hline 1990-2000 & 67.0 & 81.1 & 86.9 & 15.5 & 1.86 & 0.99 & 1.11 & 0.54 & 279.1 & 57.8 & 130.9 & 146.0 \\
\hline \multirow[t]{3}{*}{ 2000-2010 } & 78.6 & 98.4 & 77.7 & 9.5 & 3.04 & 1.35 & 1.06 & 0.35 & 804.9 & 94.4 & 195.3 & 35.4 \\
\hline & \multicolumn{4}{|c|}{ Precipitation (\%) } & \multicolumn{4}{|c|}{ Water discharge $(\%)$} & \multicolumn{4}{|c|}{ Sediment yield $(\%)$} \\
\hline & Autumn & Winter & Spring & Summer & Autumn & Winter & Spring & Summer & Autumn & Winter & Spring & Summer \\
\hline 1970-1980 & 22.1 & 33.0 & 41.3 & 3.6 & 27.3 & 29.8 & 30.3 & 12.6 & 34.5 & 24.2 & 36.6 & 4.7 \\
\hline 1980-1990 & 24.2 & 40.8 & 30.6 & 4.4 & 29.4 & 32.8 & 27.7 & 10.1 & 38.6 & 18.3 & 29.1 & 14.0 \\
\hline 1990-2000 & 26.7 & 32.4 & 34.7 & 6.2 & 41.3 & 22.1 & 24.6 & 12.0 & 45.5 & 9.4 & 21.3 & 23.8 \\
\hline 2000-2010 & 29.7 & 37.3 & 29.4 & 3.6 & 52.5 & 23.2 & 18.2 & 6.1 & 71.2 & 8.4 & 17.3 & 3.1 \\
\hline
\end{tabular}
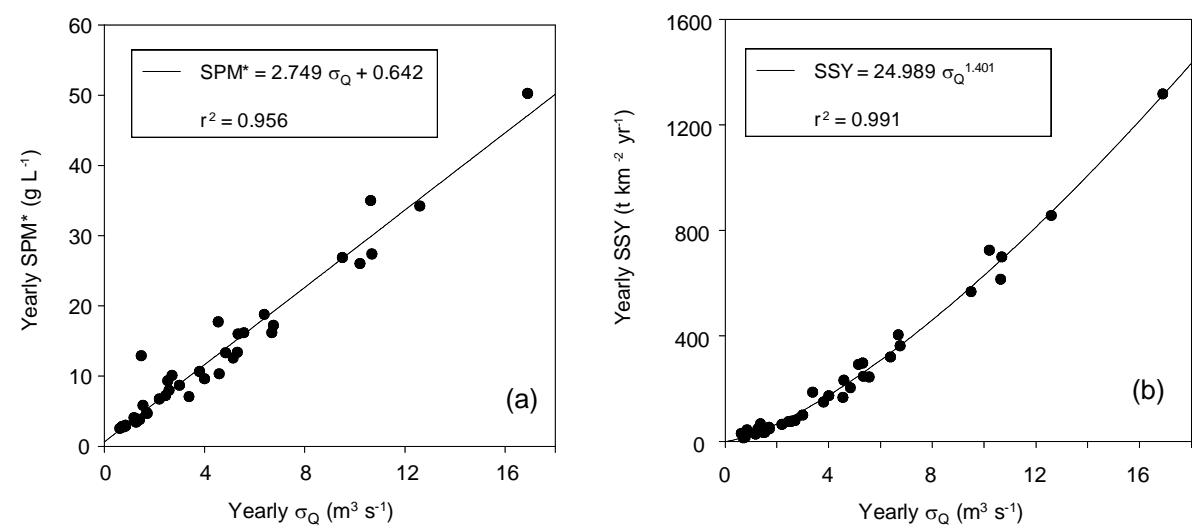

Figure 10. Yearly average of related sediment load parameters vs. intra-annual variability of daily river discharge, characterized by their annual standard deviation. (a) displays $\mathrm{SPM}^{*}$, (b) specific sediment yield.

presented in Fig. 11. The monthly values of $P, Q$ and $Q_{\text {s }}$ per decade over 40 years also clearly illustrate the absolute changes in intensity and in seasonality of the river regime (Fig. 12). The main conclusions of the analysis of $P, Q$ and $Q_{\text {s }}$ seasonal variations are the following:

- Rainfall decreased in spring and increased in autumn. Precipitation in autumn increased from 22 to $30 \%$ at the expense of spring rains (decreasing from 41 to $29 \%$ ). For the decade 2000-2010 precipitation was the same in autumn and in spring $(78 \mathrm{~mm})$ while for the decade 1970-1980 spring rainfall was $87 \%$ higher than in fall (see Table 3 and Fig. 11a).

- Average monthly rainfall from six weather stations in the river basin for 1970-1985 and 1985-2010 (Fig. 13) illustrates the changes. Two marked seasons typical of a Mediterranean climate are present (a dry season and a rainy season) but the following changes are observable: (1) differences between seasons decrease, as indicated by the CV of monthly rainfall from 57.3 in 1970-1985 to $45.9 \%$ in $1985-2000$ (there is a decrease of spring rains (March-May) and at the beginning of the cold season (November-December), as well as the strengthening of rain in the warm season (July-October) and in winter (January-February)); (2) advancement of the rainy season as evidenced by precipitation in September and October; (3) spreading of the rainy season over 9 months (September-May) for 1985-2010 from previously 7 or 8 months (from October or November onwards); (4) increased regularity of rainy season precipitation.

- Proportionally, flow decreased from winter to summer and increased dramatically in autumn from just over a quarter $(27.3 \%)$ of the flow delivered during 1970 1980 to more than one half (52.5\%) during 2000-2010 (Table 3 and Fig. 11b). Flow decreased in summer and the river became dry for much of the summer. Over the last decade, it is striking to see the difference between the average flow rates in fall and spring: the fall rate is almost 3 times that of spring with almost the same rainfall. This trend is evident over the 40 -year period (Fig. 11b). 

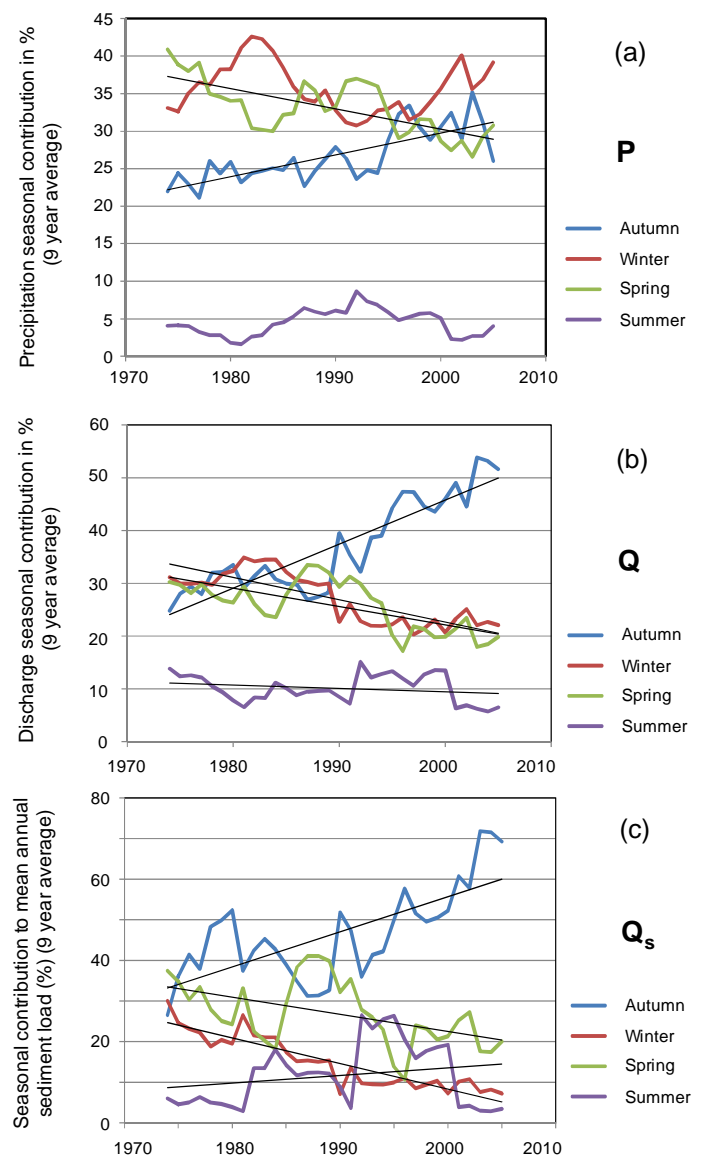

Figure 11. Trends of the seasonal indexes of precipitation (a), discharge (b) and sediment discharge (c) in the Wadi Abd basin.

- These results point towards a change in runoff as defined by the ratio $Q / P$. Considering the whole basin area, the river discharge at the Ain Hamara station averaged over 40 years corresponds to a water depth of $15 \mathrm{~mm} \mathrm{yr}^{-1}$, while the average precipitation is $264 \mathrm{~mm} \mathrm{yr}^{-1}$. For comparison, on average, $85 \%$ of rain in this region evaporates and the remaining $15 \%$ runs into surface waters or infiltrates underground storage (Sari, 2009, quoted by Benhamiche et al., 2014). On the Wadi Abd, $Q / P$ averages $5.7 \%$. We calculated the value of $Q / P$ averaged over 3 consecutive years and over 3 consecutive months (centred) and then took the average per decade (Fig. 14). It appears that the $Q / P$ ratio remains constant during the months from December to April (around $4.4 \%$, on average), it increased slightly in November and May during the decade 20002010 and it increased significantly from September to November. In other words, runoff increased, rain decreased slightly and the temperature (and therefore ETP) increased. As a consequence, infiltration will decrease and the water level in the aquifers will be lowered.
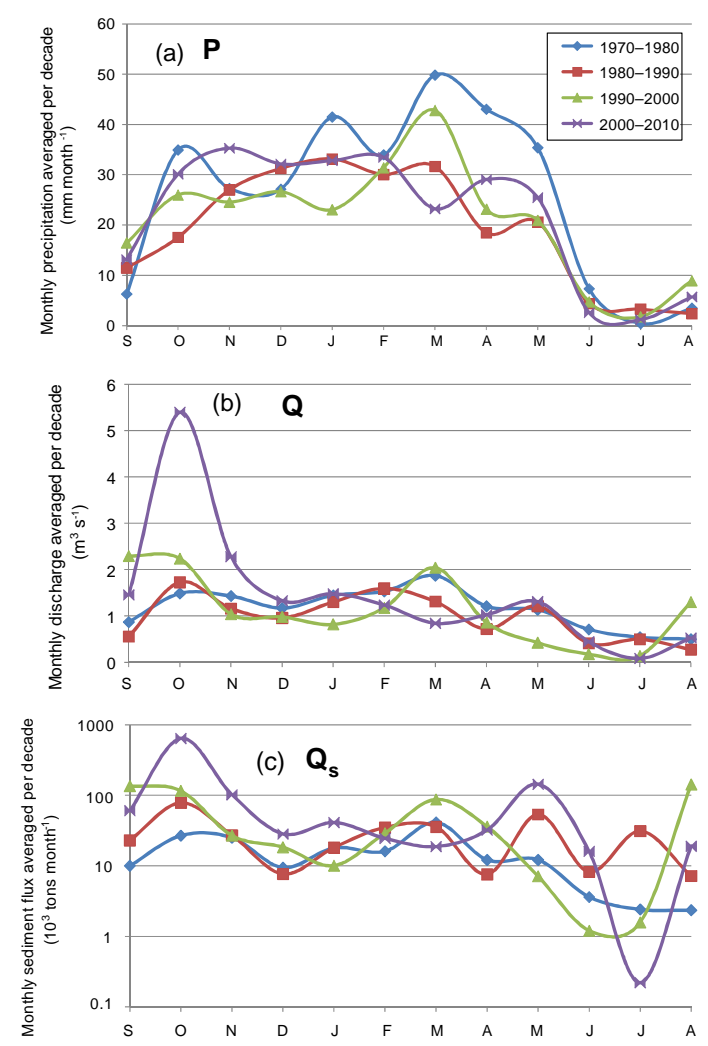

Figure 12. Monthly values of precipitation (a), $Q$ (b) and $Q_{\mathrm{s}}$ (c) averaged over decades in the Wadi Abd basin.

- In absolute values, solid discharge has been increasing in all seasons over 4 decades, but more so in the fall than in the other seasons (Table 3 and Fig. 12c). During autumn, it more than doubled from one decade to another. During the other seasons, it doubled or tripled between the 1970s and 2000s (see Table 2). While during the 1970s the Wadi Abd had two major periods of roughly equivalent sediment discharge in the fall and spring, suspended sediment loads were greater in the autumn during the 2000s (> $70 \%$ of the yearly discharge). The Wadi shifted from a regime with two equivalent seasons of sediment production to a regime with one dominant season in the 2000s. Autumn produced over 4 times more sediment than spring in the 2000s (Table 3, Fig. 11c). This phenomenon does not seem to be due to some exceptional floods because the trend is observable over 4 consecutive decades (Fig. 11c). 


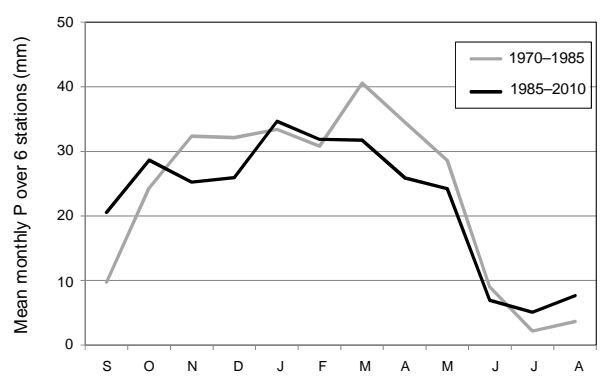

Figure 13. Monthly values of precipitation averaged over six stations, for the two periods 1970-1985 and 1985-2010.

\section{Discussion}

\subsection{Interannual variations}

\subsubsection{Hydrology and climate change over 40 years}

Temperature increased rapidly between the 1970s and 1980s $\left(+0.87^{\circ} \mathrm{C}\right.$, on average, at Chlef). The increases were lower during the 3 following decades. An increase in temperature of $1.6^{\circ} \mathrm{C}$ between $1977-1979$ and $2000-2006$ was noted by Dahmani and Meddi (2009) for the Wadi Fekan basin in west Algeria and Bakreti et al. (2013) also showed a significant trend of increasing temperature in spring by $0.0183^{\circ} \mathrm{C}$ per year in the Tafna basin in west Algeria over the same period. However, temperature has not increased as rapidly over the 20th century (Fig. 6) and as mentioned by IPCC (2013), "trends based on short records are very sensitive to the beginning and end dates and do not in general reflect long-term climate trends." The longest available time series of temperature in Algeria was measured at Dar El Beida near Algiers. At this station, average temperature increased by $0.62{ }^{\circ} \mathrm{C}$ between 1850-1900 (29 yearly values available) and 20032012 (Fig. 6), while it increased between 1880 and 2012 by $0.85^{\circ} \mathrm{C}$ globally (IPCC, 2013).

A global trend towards increasing temperatures and increasing dryness in Algeria from the 1970s onwards has already been described (Meddi and Meddi, 2009). Over the period 1923-2006, north Algeria experienced an alternation of wet periods (1923-1939, 1947-1973) and dry periods (1939-1946 and from 1974 onwards) (Benhamiche et al., 2014). Over 70 years in the Wadi Fekan, Dahmani and Meddi (2009) showed that the period 1943-1960 was rather wet, that 1960-1975 was average, and that the period 1975 onwards (up to the end of their data set in 2004) was dry and of an exceptional long duration. Using three different statistical tests (Pettitt, Lee-Heghinian and Hubert), Meddi and Meddi (2007) shown that a shift was observed between 1973 and 1980 over most of the rain gauges in Algeria. In northwest Algeria, a shift was noticed in 1973 in winter rainfall and between 1974 and 1980 in spring rainfall, both of these shifts being responsible for the yearly rainfall deficit (Meddi and Talia, 2008). From the rainfall data set at the Ain Hamara

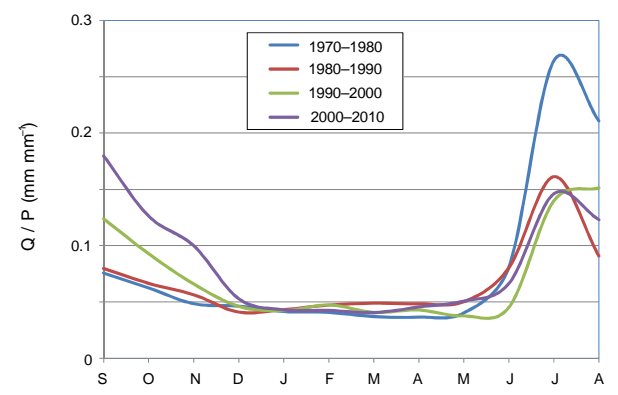

Figure 14. Monthly values of the ratio $Q / P$ averaged over decades.

station between 1968 and 2007, Hallouz et al. (2013) showed that the break in annual rainfall occurred in 1976 and calculated a deficit of $19 \%$ between 1968-1976 (304 $\mathrm{mm} \mathrm{yr}^{-1}$ ) and 1976-2007 (247 $\left.\mathrm{mm} \mathrm{yr}^{-1}\right)$. At the stations Ponteba and Rechaiga, near to the Abd basin, the trends of decreasing total precipitation and of increasing mean length of dry spells were amongst the five highest in the Maghreb area over the 22 stations considered by Tramblay et al. (2013, see their Fig. 8).

As a consequence of the decrease of rainfall after the 1970s break which was observed in most basins of western Algeria, river discharges were generally seen to decrease as well. Meddi and Hubert (2003) showed that the decrease in river discharge varied between -37 and $-70 \%$ from eastern Algeria to western Algeria. In the Mecta basin in northwest Algeria, runoff was estimated to be $28-36 \%$ lower in 19762002 as compared to 1949-1976 (Meddi et al., 2009). In the Tafna basin, also in northwest Algeria, Ghenim and Megnounif $(2013 \mathrm{a}, \mathrm{b})$ showed that the decrease in precipitation after the break point was, on average, $29 \%$ over the whole basin (especially in winter and spring) and was accompanied by a decrease of $60 \%$ in river flow.

In contrast, the Wadi Abd behaved differently in that river discharge increased. The counterintuitive increase of runoff with decreasing rainfall has also been observed in the Sahel and is referred to as "the Sahelian paradox" (see Mahé and Paturel, 2009; Mahé et al., 2012). A closer look at the seasonal variations of the different parameters shows that $Q$ decreased in winter and spring but that $Q / P$ increased in autumn when rainfall increased. Overall $Q$ increased. The decrease of rainfall in spring and its low level in summer may have led to a change in vegetation cover which would in turn decrease infiltration. However, although studying the vegetation dynamics of the basin goes beyond the scope of this study, this aspect could be investigated in the future using satellite data, for example.

\subsubsection{What is the influence of large-scale circulation indices?}

Changes in precipitation are derived from atmosphericoceanic signals (Milliman et al., 2008; Giuntoli et al., 2013). 
Low-frequency fluctuations related to climate change are modulated with higher-frequency interannual fluctuations, such as ENSO (El Niño-Southern Oscillation), NAO (North Atlantic Oscillation), AMO (Atlantic Multidecadal Oscillation) or MO (Mediterranean Oscillation). Tramblay et al. (2013) showed that the precipitation amounts and the number of dry days over the Maghreb were significantly correlated with the MO and NAO patterns. MO and NAO showed positive trends from the 1970s onwards which could explain the trend towards decreasing frontal conditions over the Mediterranean basin and thus increasing droughts.

Interannual influence by the Austral oscillation ENSO over Algeria was shown to be higher in northwest Algeria on the highest discharges than on the average discharge. The maximum $Q$ seems to be smaller during El Niño and higher during La Niña in northwest Algeria (Ward et al., 2014). The frequency of extreme rainfall events shows the highest correlation with the Mediterranean Oscillation index in Algiers and with the Southern Oscillation index in Oran (Taibi et al., 2014).

In this study, no significant correlation was established between a series of hydrological parameters in the Wadi Abd and the Southern Oscillation index. The average of AMO per hydrologic year was calculated from its monthly values. AMO has increased from 1970s to the 2000s, with negative values until 1993-1994, then positive values thereafter (except in 1996-1997). Its decadal average was -0.25 in the $1970 \mathrm{~s},-0.12$ in the $1980 \mathrm{~s}, 0.0$ in the $1990 \mathrm{~s}$ and 0.18 in the 2000s. AMO and the discharge variability of the Wadi Abd within the year increased coincidently. The yearly AMO values have a coefficient of determination of 0.226 when correlated with the standard deviation of daily river discharges within the year, a proxy for the variability of daily discharge. However, this information does not allow us to conclude that the Atlantic Multidecadal Oscillation is responsible for hydrological changes in the Wadi Abd basin.

\subsubsection{Break point in 1985-1986: change of flow regime}

The several weeks of dry river for the first time in 19851986 (49 days) can be considered as a threshold effect, which marks the start of a new flow regime. The appearance of a dry regime is a break, a fully nonlinear phenomenon. It has strong consequences for water infiltration and groundwater recharge, on the seasonality, intensity and type of floods, and in turn, on erosion and sediment transport. The year 1985 is also a pivotal year for recent climate change as evidenced by the rapid increase in global mean air temperature anomaly from that year until 1993 (Fig. 1 in Lockwood and Fröhlich, 2007). The hypothesis of a temporary warming caused by dust emitted during the eruption of Mount Pinatubo had been advanced to explain the warming since 1985, but climate scientists later recognized that the temperature anomaly has been increasing since 1993, reaching about $0.6^{\circ} \mathrm{C}$ by 2007 compared to the global average temperature calculated for the period 1951-1980 (Lockwood and Fröhlich, 2007).

This threshold is coincident with hydrological shifts in the Tafna basin in northwest Algeria. Bakreti et al. (2013) analysed the baseflow and baseflow index of five of the Tafna's sub-basins between 1976 and 2006 and found ruptures of the baseflow index between 1984 and 1990 depending on the sub-basin, in 1984, 1985 and 1990 in the mountains, and in 1985 and 1986 in the plain. These changes in flow regimes in the Tafna basin were likely caused by shifts in rainfall in the late 1970s in the Mounts of Tlemcen and early 1980s in the plains (Ghenim and Megnounif, 2013a).

\subsubsection{Shift of the onset of the first summer flood}

The analysis of the time series of daily flows enables the determination of the start of the first summer flood. The average daily flow per decade suddenly increases the day at which the first summer flood occurred, at least once in the decade. By observing these decadal averaged daily flows, there is no ambiguity on the start of the earliest flood by decade:

- In 1970-1980, the first flood starts on 6 September with an average 4-day discharge (6-9 September) of $1.59 \mathrm{~m}^{3} \mathrm{~s}^{-1}$, while it was, on average, $0.58 \mathrm{~m}^{3} \mathrm{~s}^{-1}$ over the 4 previous days.

- In 2000-2010, the first flood of summer starts on $8 \mathrm{Au}$ gust with an average 4-day discharge (8-11 August) of $2.03 \mathrm{~m}^{3} \mathrm{~s}^{-1}$, while it was, on average, $0.03 \mathrm{~m}^{3} \mathrm{~s}^{-1}$ from 4 to 7 August.

During the 2000s, the first flood in summer started close to 1 month before that of the 1970 s and the magnitude was $27 \%$ higher. It can be asked if this trend was observable over the 40 -year period or only between 2 specific decades. The analysis of mean dates and discharges of the first flood in the late dry season gave the following results for the intermediate decades:

- In 1980-1990, the first flood started, on average, on 31 August with a 4-day average discharge (31 August3 September) of $2.69 \mathrm{~m}^{3} \mathrm{~s}^{-1}$, while the average rate over the 4 previous days was $0.13 \mathrm{~m}^{3} \mathrm{~s}^{-1}$.

- In 1990-2000, the first flood started, on average, on 22 August with a 4-day average discharge (22-25 August) of $7.67 \mathrm{~m}^{3} \mathrm{~s}^{-1}$, while the average rate over the 4 previous days was $0.33 \mathrm{~m}^{3} \mathrm{~s}^{-1}$. The existence of a precursor peak on 17 August, which was not observed in previous decades, was also observed.

It therefore appears that the date of the first flood advanced by about 10 days each decade over the previous 40 years. The shift in the onset of the first flood in summer probably has important consequences on flow and erosion rates. 


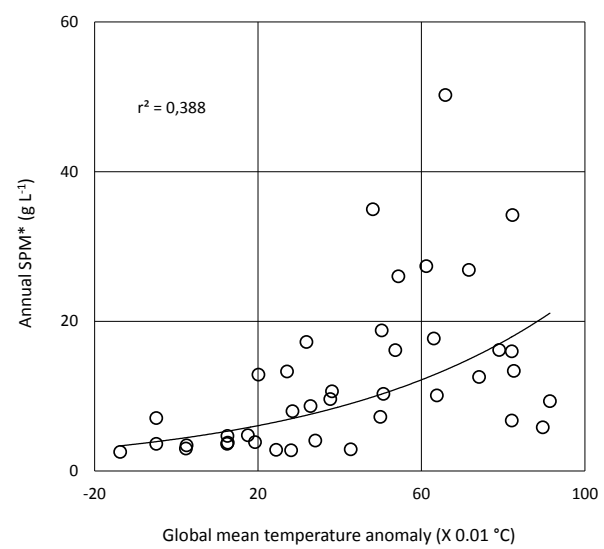

Figure 15. Variations of SPM* against the global mean temperature anomaly.

\subsection{Relationships between several parameters and sediment yield}

\subsubsection{Temperature and sediment yield}

The curve showing annual suspended load versus the global air temperature anomaly (base period 1951-1980) calculated by hydrological year from monthly data provided by NOAA (Hansen et al., 2010; GISTEMP Team, 2015) shows a correlation between the sediment yield and ongoing climate change $\left(r^{2}=0.388\right.$, Fig. 15$)$.

\subsubsection{Precipitation and sediment yield}

Many authors studied the variations of sediment load per unit of catchment area against annual rainfall (e.g. Summerfield and Hulton, 1994) or effective rainfall (e.g. Langbein and Schumm, 1958). On the Wadi Abd, annual rainfall fell sharply between the 1970s and the 1980s, then slightly increased over the following decades. Meanwhile, yearly sediment concentration and suspended sediment discharge have increased. The comparison of their respective variations shows a lack of correlation between precipitation and annual sediment yield $\left(r^{2}<0.1\right.$, regardless of the type of regression considered). Regarding the relationship between precipitation and erosion, if there are correlations between their spatial variations reported in the literature (though with a strong scatter, see Riebe et al., 2001), our study shows that the temporal variations of precipitation and sediment yield are not correlated in the Wadi Abd. This may be due to the change of flow regime within the study period.

\subsubsection{Runoff and sediment yield}

Although runoff was noted to have a limited impact on the distribution of sediment yield at regional or global scales by Aalto et al. (2006), Syvitski and Milliman (2007) and Vanmaercke et al. (2014), the temporal variability in precipita- tion, runoff (or discharge) and consecutive vegetation cover was shown to be locally the main impact on fluvial sediment load (see Vanmaercke et al., 2014, p. 360). On the Wadi Abd, the yearly suspended sediment load was highly correlated with discharge ( $Q$ mean or its highest percentiles) and to its intra-annual fluctuation (Fig. 10). Although the river regime shift clearly impacted several parameters, the relationship between yearly sediment load and discharge variability did not change over the 40 -year study period.

\subsection{On the use of double-mass curves to determine the climate change and anthropogenic influences}

Double-mass curves are often used to determine the impact of developments such as dams on sediment discharge (e.g. Lu et al., 2013). Our findings warn about extrapolations that could be wrongly made to quantify the impact of a development by extending the double-mass curves. Indeed, this study shows that the double-mass curve can change its slope (here increasing) when the flow regime change is driven by seasonal temporal variation in precipitation and runoff that is not linked to any specific anthropogenic activity (such as a dam impoundment) within the basin.

\subsection{Physical meaning of rating parameters $a$ and $b$}

\subsubsection{Interannual variation of $(a, b)$}

Since $C=a Q^{b}$, with $b \neq 0$, then $C(1)=a$. $a$ thus represents the sediment concentration when the river discharge is $1 \mathrm{~m}^{3} \mathrm{~s}^{-1}$, and $b$ reflects the sensitivity of concentration to discharge variation. The general formula $\ln C=\ln \left(a Q^{b}\right)$ provides:

$d C / C=b d Q / Q$

$b=d C / d Q \cdot Q / C=1 / a \cdot d C / d Q \cdot Q^{(1-b)}$

thus $b$ varies almost like 1/a (Asselman, 2000). Many papers discuss the physical meaning of the rating parameters $a$ and $b$ (see AO2007) and try to connect their values to physiographical characteristics, vegetation cover or hydrometeorological forcing.

The river's regime change is accompanied by a change in the $(a, b)$ pairs of rating curves defined for multi-year periods such that $a$ increases and $b$ decreases (Table 2), following:

$b=-0.294 \ln a+0.912\left(r^{2}=0.582\right)$
$\ln b=-0.188 a+0.042\left(r^{2}=0.649\right)$.

Equation (5a) is very similar to that presented by Iadanza and Napolitano (2006) for the Tiber River after the construction of a dam $\left(b=-0.3815 \ln a+0.7794, r^{2}=0.992\right)$. Before the construction of this dam, another relationship corresponded to more than 3 times higher sediment yields. Asselman (2000) has suggested interpreting the regression lines in a $\ln a-b$ graph as different sediment transport regimes. 


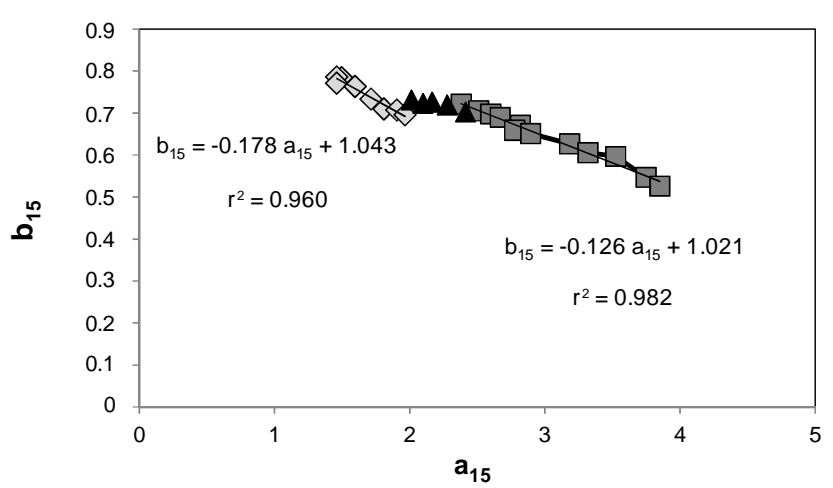

Figure 16. Relationship between the rating curves parameters averaged over 15 years.

On the Wadi Abd, the change in sediment transport regime is not evident from the yearly $(a, b)$ values but it becomes clearly observable when considering $a$ and $b$ values averaged over moving periods of several years. The best correlations were obtained for running averages over 15 years named $a_{15}$ and $b_{15}(N=25$, from $1970-1985$ to $1995-2010$, see Fig. 16). The available data set does not allow us to determine if results obtained from averaging over longer periods would perform best.

The time evolution of the moving average pair $\left(a_{15}, b_{15}\right)$ clearly shows a first relationship with the values dominated by the pre-1985 regime ( 8 values from 1970-1985 to 19771991), another one for the values predominantly after 1990 (12 values from 1983-1997 to 1995-2010), both with $a_{15}$ increasing and $b_{15}$ decreasing, and a transitional regime centred on the period 1985-1990 (Fig. 16). During the transition period centred over $1985-1990, b_{15}$ was almost constant (between 0.72 and 0.74 ) while $a_{15}$ was increasing from 2.01 to 2.34. During the period 1985-1991, the yearly values of $b$ varied very little (between 0.653 and 0.672 ) while yearly $a$ increased significantly from 1.81 in $1985-1986$ to 3.23 in 1990-1991. Higher $a$ and lower $b$ values are in the literature typical of highly arid river basins, such as the ephemeral Nahal Eshtemoa in Israel, where $a=16.98$ and $b=0.43$ (Alexandrov et al., 2003).

As the break points were coincident, it is possible to analyse the change (of $a_{15}$ and $b_{15}$ ) in terms of shift of hydrological regime. However, if the new hydrological regime was immediate from 1985 onwards, the change in the $C-Q$ relationship was only evidenced in the Wadi Abd at midterm, considering 15 -year average values.

\subsubsection{Parameters that explain $a$ (or $b$ )}

The coefficient of determination between $a$ and SSY is low at the annual scale but higher when we consider the moving averages of $a$ and SSY over 15 years. The SSY explained $95.2 \%$ of the variance in the interannual scale (Fig. 17), much more than the average river flow did $\left(r^{2}=0.839\right) . b_{15}$



Figure 17. Relationship between the rating curve parameter a averaged over 15 years and the averaged values of specific sediment yield over 15 years.

showed a lower correlation with the SSY $\left(r^{2}=0.853\right)$ than $a_{15}$ did.

In summary, the moving average of $a$ is strongly correlated to specific sediment yield over the same moving period of 15 years, and the moving average of $b$ can be deduced from $a$ using the relationship which is given in Fig. 16 as a function of flow regime, either perennial or intermittent.

\subsubsection{Validity range of rating curves}

The estimation of sediment yield from flow measurements and a rating curve is still acceptable throughout the study period (Fig. 5). However, the pairs $(C, Q)$ become increasingly scattered with time around the best-fit curve, as attested by the decrease of the coefficient of determination from one decade to another (Table 2).

Intermittent flows induce a stronger dependency of river behaviour on antecedent wetness (Beven, 2002) and antecedent weathering, i.e. a strong dependency on memory through threshold and hysteresis effects. With increasing memory effects, coincident values of $C$ and $Q$ become less dependent on each other and the rating curves less suitable to model their relation. The study of sediment dynamics in the Wadi Abd in the future will thus likely require a more appropriate method than rating curves, such as the study of each individual flood, like Megnounif et al. (2013) did in the Wadi Sebdou. This finding may have consequences on water management as well. When dealing with rating curves, water discharge must be recorded at frequent intervals, although measurements of concentration can be sparser. When rating curves cannot be applied, river discharge and sediment concentration should be both frequently and simultaneously measured. 


\section{Conclusions}

In response to climate change which resulted in an increase in temperature of around $1.1^{\circ} \mathrm{C}$ between the 1970s and 2000s at Chlef, rainfall moved forward during the late warm season and the watershed of Wadi Abd experienced a significant change in flow regime and an increased variability at both the inter-annual and intra-annual levels. These changes ultimately led to a dramatic and continuous increase in sediment load over 4 decades (on average, $84 \%$ more every decade as compared to the previous one).

The main result of our analysis is the shift of the onset of the first summer flood that occurred 1 month earlier in the 2000s than in the 1970s. This shift is likely responsible for the cascading effects on the hydrological regime of the Wadi Abd. In particular, earlier floods during the warmer season have higher evaporation which limits the groundwater storage. A parallel study of seasonal changes in vegetation cover is needed to provide additional information.

The increase in erosion of the watershed (coefficient $a$ ) is accompanied by a decrease in the coefficient $b$. The traditional rating curves approach, which was applicable when the river was perennial, is now less adapted to model the behaviour of the river (Table 2). This could be explained by a more pronounced hysteresis phenomenon, which is consistent with the change of hydrological regime in the dry season thereby limiting the utility of rating curves to model $C-Q$ relationships.

The rapid change in sediment regime which is instantaneously driven by the changing flow regime should be distinguished from the slow change in the concentration-flow relationship. The change in flow regime can be precisely dated in May-July 1986 (with 49 consecutive dry days), while the change in the $C-Q$ relationship requires averaging over several years of $a, b$ and specific sediment yield to become evident. Such inertial effect may be attributed to the time for the basin soil properties (such as humidity) or vegetation to adapt to the new climate conditions. It likely depends, amongst other factors, on underground water storage, and thus on basin lithology and infiltration history. Over the Wadi Abd basin, the time needed for the flow regime to change after the dryness settlement in early 1970s (see Fig. 6) is estimated as being around 15 years in this study.

The present analysis only includes hydrological parameters. Management programs that were conducted to fight erosion in Algeria from the 1960s until the 1990s by reforesting and setting up banks over cultivated marl and clay areas proved to be little or not efficient (Touaibia, 2010). Human activities may have influenced the hydrological regime change and increased erosion, in particular through firewood cutting during economically difficult periods (1990s), however the shift was shown to occur earlier. The lack of data on land use and land cover changes over 40 years does not allow us to isolate the factors directly related to climate change from those related to other anthropogenic activities. How- ever, the small population, the low coverage of pasture (see Fig. 2d), cultivated areas and vegetation $(43 \%)$ in the basin and the small volume of reservoirs (nominally $2.3 \%$ of the annual discharge, and silted up to $70 \%$ ) make us think that in this system the effects of climate change dominate anthropogenic effects. The quantification of forcing changes on sediment sources (raindrop erosion, sheet erosion, rill erosion, gully erosion and stream channel erosion) may be investigated in situ (e.g. Poesen et al., 2003) and/or estimated using a numerical model of the hydrologic and sedimentological functioning of the basin, such as WEPP (Nearing et al., 1989), EUROSEM (Morgan et al., 1998) or SWAT (Neitsch et al., 2011). Such a model could help us to test hypotheses and quantify or at least estimate the effects of different forcing changes (temperature, runoff, vegetation, etc.) in future studies.

It is important to emphasize that it is impossible to define long-term hydrological averages in the context of a changing flow regime. The example of the Wadi Abd shows that the difficulty is challenging with regard to sediment transport in suspension, since changes of flux cannot be counted as a fraction but can reach an order of magnitude.

Changes in flow regime in relation to climate change can be investigated using climate models. Das et al. (2013), using 16 climate projections, showed that more intense floods of a return period 2-50 years should occur in the Sierra Nevada, regardless of the rainfall variation. The recent changes in the Wadi Abd show that extreme events with increasing variability already occur in the basin. Over Algeria, an increase of $1-2{ }^{\circ} \mathrm{C}$ in temperature could induce a reduction of $10 \%$ in precipitation before the end of the 21st century (Benhamiche et al., 2014) with unknown consequences on erosion and sediment transport. Lu et al. (2013) calculated the impact on sediment loads of every $1 \%$ change in precipitation or river discharge in large Chinese rivers. Such a calculation has no meaning in our basin since the rainfall and discharge were not monotonic (severe decrease in the 1970s then slight increase during 30 years) while the sediment loads have always increased. The difficulty of forecasting climate changedriven impacts on sediment yield due to nonlinear effects has been underlined by geomorphologists (see Goudie, 2006; Jerolmack and Paola, 2010; Coulthard et al., 2012; Knight and Harrison, 2013). The present study illustrates that the change in flow regime induced a fully nonlinear effect between river discharge and sediment yield. This needs be considered in forecasts especially in small river basins in semiarid areas.

Changes in erosion and sediment transport under new climate constraints will induce changes from the middle to long term that decision-makers must integrate into water resources management, habitat status, agricultural adaptation (O'Neal et al., 2005), landscape evolution (Temme and Veldkamp, 2009) as well as in many other environmental adaptations (Ouillon, 1998). We thus encourage the local adaptation of sampling strategies and measurements to take into account 
changing in flow regimes. Furthermore, due to the uncertainty of water resources and erosion in the Maghreb (Taabni and El Jihad, 2012) and in the Mediterranean basin (Nunes et al., 2008), we also encourage the development of studies on long-term sediment transport in north African basins, in connection with changes in forcing factors.

Acknowledgements. The authors warmly thank Abda Leila from the Hydrometry office, Ould Lamara Arezki from the Climatology Office of the Agence Nationale des Ressources Hydrauliques (ANRH) in Alger, Boudalia Mohamed from the Hydrometry Office of the ANRH in Oran, and all the staff of ANRH who participated to the field measurements at Ain Hamara station. They also acknowledge Abderrezak Kamel Toubal for his help in drawing Figs. 1 and 2. Two anonymous reviewers are warmly thanked for their reviews and comments on previous versions of this paper. The editor, Efrat Morin, is gratefully acknowledged. Emma Rochelle-Newall, a native English speaker, is warmly thanked for the English corrections.

Edited by: E. Morin

\section{References}

Aalto, R., Dunne, T., and Guyot, J. L.: Geomorphic controls on Andean denudation rates, J. Geol., 114, 85-99, 2006.

Achite, M. and Ouillon, S.: Suspended sediment transport in a semiarid watershed, Wadi Abd, Algeria (1973-1995), J. Hydrol., 343, 187-202, 2007.

Alexandrov, Y., Laronne, J. B., and Reid, I.: Suspended sediment concentration and its variation with water discharge in a dryland ephemeral channel, northern Negev, Israel, J. Arid Environ., 53, 73-84, 2003.

Asselman, N. E. M.: Fitting and interpretation of sediment rating curves, J. Hydrol., 234, 228-248, 2000.

Bakreti, A., Braud, I., Leblois, E., and Benali, A.: Analyse conjointe des régimes pluviométriques et hydrologiques dans le basin de la Tafna (Algérie Occidentale), Hydrolog. Sci. J., 58, 133-151, 2013.

Bates, B. C., Kundzewicz, Z. W., Wu, S., and Palutikof, J. P. (Eds.): Climate Change and Water. Technical Paper of the Intergovernmental Panel on Climate Change, IPCC Secretariat, Geneva, 210 pp., 2008.

Benhamiche, N., Madani, K., and Laignel, B.: Chapter 12 Impact of climate change on water resources in Algeria, in: Vulnerability of agriculture, water and fisheries to climate change: toward sustainable adaptation strategies, edited by: Behnassi, M., Syomiti Mutengé, M., Ramachandran, G., and Shelat, K. N., Springer, Dordrecht, 193-205, doi:10.1007/978-94-017-8962-2_12, 2014.

Beven, K.: Runoff generation in semi-arid areas, in: Dryland rivers: hydrology and geomorphology of semi-arid channels, edited by: Bull, L. J. and Kirkby, M. J., Wiley, London, 57-106, 2002.

Coulthard, T. J., Ramirez, J., Fowler, H. J., and Glenis, V.: Using the UKCP09 probabilistic scenarios to model the amplified impact of climate change on d rainage basin sediment yield, Hydrol. Earth Syst. Sci., 16, 4401-4416, doi:10.5194/hess-16-44012012, 2012.
Dahmani, A. and Meddi, M.: Climate variability and its impact on water resources in the catchment area of the Wadi Fekan Wilaya of Mascara (West Algeria), Eur. J. Sci. Res., 36, 458-472, 2009.

Das, T., Maurer, E. P., Pierce, D. W., Dettinger, M. D., and Cayan, D. R.: Increases in flood magnitudes in California under warming climates, J. Hydrol., 501, 101-110, 2013.

Déry, S. J., Stieglitz, M., McKenna, E. C., and Wood, E. F.: Characteristics and trends of river discharge into Hudson, James, and Ungava bays, 1964-2000, J. Climate, 18, 2540-2557, 2005.

Durand, N., Fiandrino, A., Fraunie, P., Ouillon, S., Forget, P., and Naudin, J. J.: Suspended matter dispersion in the Ebro ROFI: an integrated approach, Cont. Shelf Res., 22, 267-284, 2002.

El Mahi, A., Meddi, M., and Bravard, J. P.: Analyse du transport solide en suspension dans le bassin versant de l'Oued El Hammam (Algérie du Nord), Hydrolog. Sci. J., 57, 1642-1661, 2012.

Gao, Z. L., Fu, Y. L., Li, Y. H., Liu, J. X., Chen, N., and Zhang, X. P.: Trends of streamflow, sediment load and their dynamic relation for the catchments in the middle reaches of the Yellow River over the past five decades, Hydrol. Earth Syst. Sci., 16, 3219-3231, doi:10.5194/hess-16-3219-2012, 2012.

Ghenim, A. N. and Megnounif, A.: Analyse des précipitations dans le Nord-Ouest algérien, Sécheresse, 24, 107-114, 2013a.

Ghenim, A. N. and Megnounif, A.: Ampleur de la sécheresse dans le basin d'alimentation du barrage Meffrouche (Nord-Ouest de l'Algérie), Physio-Géo, 7, 35-49, 2013b.

GISTEMP Team: GISS Surface Temperature Analysis (GISTEMP), NASA Goddard Institute for Space Studies, http://data.giss.nasa. gov/gistemp/, last access: 8 December 2015.

Giuntoli, I., Renard, B., Vidal, J. P., and Bard, A.: Low flows in France and their relationship to large-scale climate indices, J. Hydrol., 482, 105-118, 2013.

Gomez, B., Cui, Y., Kettner, A. J., Peacock, D. H., and Syvitski, J. P. M.: Simulating changes to the sediment transport regime of the Waipaoa River, New Zealand, driven by climate change in the twenty-first century, Global Planet. Change, 67, 153-166, 2009.

Goudie, A. S.: Global warming and fluvial geomorphology, Geomorphology, 79, 384-394, 2006.

Hallouz, F., Meddi, M., and Mahé, G.: Modification du régime hydroclimatique dans le basin de l'oued Mina (Nord-Ouest d'Algérie), Revue Sci. Eau, 26, 33-38, 2013.

Hancock, G. R.: A catchment scale assessment of increased rainfall and storm intensity on erosion and sediment transport for Northern Australia, Geoderma, 152, 350-360, 2009.

Hancock, G. R. and Coulthard, T. J.: Channel movement and erosion response to rainfall variability in southeast Australia, Hydrol. Process., 26, 663-673, 2011.

Hansen, J., Ruedy, R., Sato, M., and Lo, K.: Global surface temperature change, Rev. Geophys., 48, RG4004, doi:10.1029/2010RG000345, 2010.

Houyou, Z., Bielders, C. L., Benhorma, H. A., Dellal, A., and Boutemdjet, A.: Evidence of strong land degradation by wind erosion as a result of rainfed cropping in the Algerian steppe: a case study at Laghouat, Land Degrad. Develop., doi:10.1002/ldr.2295, in press, 2014.

Iadanza, C. and Napolitano, F.: Sediment transport time series in the Tiber River, Phys. Chem. Earth, 31, 1212-1227, 2006.

IPCC: Climate Change 2013: The Physical Science Basis, in: Contribution of Working Group I to the Fifth Assessment Report of the Intergovernmental Panel on Climate Change, edited by: 
Stocker, T. F., Qin, D., Plattner, G.-K., Tignor, M., Allen, S. K., Boschung, J., Nauels, A., Xia, Y., Bex, V., and Midgley, P. M., Cambridge University Press, Cambridge, UK and New York, NY, USA, 1535 pp., 2013.

Jerolmack, D. J. and Paola, C.: Shredding of environmental signals by sediment transport, Geophys. Res. Lett., 37, L19401, doi:10.1029/2010GL044638, 2010.

Jones, P. D., Lister, D. H., Osborn, T. J., Harpham, C., Salmon, M., and Morice, C. P.: Hemispheric and large-scale land surface air temperature variations: an extensive revision and an update to 2010, J. Geophys. Res., 117, D05127, doi:10.1029/2011JD017139, 2012.

Kassoul, M., Abdelgader, A., and Belorgey, M.: Caractérisation de la sedimentation des barrages en Algérie, Rev. Sci. Eau, 3, 339 $358,1997$.

Knight, J. and Harrison, S.: The impacts of climate change on terrestrial Earth surface systems, Nat. Clim. Change, 3, 24-29, 2013.

Langbein, W. B. and Schumm, S. A.: Yield of sediment in relation to mean annual precipitation, T. Am. Geophys. Un., 39, 10761084, 1958.

Lockwood, M. and Fröhlich, C.: Recent oppositely directed trends in solar climate forcings and the global mean surface air temperature, P. Roy. Soc. A, 463, 2447-2460, doi:10.1098/rspa.2007.1880, 2007.

Louamri, A., Mebarki, A., and Laignel, B.: Variabilité interannuelle et intra-annuelle des transports solides de l'Oued Bouhamdane, à l'amont du barrage Hammam Debagh (Algérie orientale), Hydrolog. Sci. J., 58, 1559-1572, 2013.

Lu, X. X., Ran, L. S., Liu, S., Jiang, T., Zhang, S. R., and Wang, J. J.: Sediment loads response to climate change: A preliminary study of eight large Chinese rivers, Int. J. Sed. Res., 28, 1-14, 2013.

Mahé, G. and Paturel, J. E.: 1896-2006 Sahelian annual rainfall variability and runoff increase of Sahelain Rivers, C. R. Geoscience, 314, 538-546, 2009.

Mahé, G., Lienou, G., Descroix, L., Bamba, F., Paturel, J. E., Laraque, A., Meddi, M., Habaieb, H., Adeaga, O., Dieulin, C., Chahnez Kotti, F., and Khomsi, K.: The rivers of Africa: witness of climate change and human impact on the environment, Hydrol. Process., 27, 2105-2114, 2012.

Meade, R. H. and Moody, J.A.: Causes for the decline of suspendedsediment discharge in the Mississipi River system, 1940-2007, Hydrol. Process., 24, 35-49, 2010.

Meddi, M. and Hubert, P.: Impact de la modification du régime pluviométrique sur les ressources en eau du nord-ouest de l'Algérie, IAHS Publ. no. 278, in: Hydrology of the Mediterranean and Semiarid Regions, edited by: Servat, E., Najem, W., Leduc, C., and Shakeel, A., IAHS Press, Wallingford, UK, 229-235, 2003.

Meddi, H. and Meddi, M.: Variabilité spatiale et temporelle des précipitations du Nord-Ouest de l'Algérie, Geographica Technica no. 2/2007, 49-55, 2007.

Meddi, H. and Meddi, M.: Variabilité des précipitations annuelles du Nord-Ouest de l'Algérie, Sécheresse, 20, 57-65, 2009.

Meddi, M. and Talia, A.: Pluviometric regime evolution in the North of Algeria, Arab. Gulf J. Sci. Res., 26, 152-162, 2008.

Meddi, M., Talia, A., and Martin, C.: Evolution récente des conditions climatiques et des écoulements sur le basin versant de la Macta (nord-ouest de l'Algérie), Physio-Géo, 3, 61-84, 2009.
Megnounif, A., Terfous, A., and Ouillon, S.: A graphical method to study suspended sediment dynamics during flood events in the Wadi Sebdou, NW Algeria (1973-2004), J. Hydrol., 497, 24-36, 2013.

Memariam, H., Balasundram, S. K., Talib, J. B., Sood, A. M., and Abbaspour, K. C.: Trend analysis of water discharge and sediment load during the past three decades of development in the Langat basin, Malaysia, Hydrolog. Sci. J., 57, 1207-1222, 2012.

Milliman, J. D., Farnsworth, K. L., Jones, P. D., Xu, K. H., and Smith, L. C.: Climatic and anthropogenic factors affecting river discharge to the global ocean, 1951-2000, Global Planet. Change, 62, 187-194, 2008.

Morgan, R. P. C., Quinton, J. N., Smith, R. E., Govers, G., Poesen, J. W. A., Auerswald, K., Chisci, G., Torri, D., and Styczen, M. E.: The European Soil Erosion Model (EUROSEM): A dynamic approach for predicting sediment transport from fields and small catchments, Earth Surf. Proc. Land., 23, 527-544, 1998.

Nanson, G. C., Tooth, S., and Knighton, A. D.: A global perspective on dryland rivers: perceptions, misconceptions and distinctions, in: Dryland rivers: hydrology and geomorphology of semi-arid channels, edited by: Bull, L. J. and Kirkby, M. J., Wiley, London, 17-54, 2002.

Nearing, M. A., Foster, G. R., Lane, L. J., and Finkner, S. C.: A process-based soil erosion model for USDA-Water Erosion Prediction Project technology, T. ASAE, 32, 1587-1593, 1989.

Neitsch, S. L., Arnold, J. G., Kiniry, J. R., and Williams, J. R.: Soil and Water Assessment Tool - Theoretical Documentation version 2009, Texas Water Inst. Techn. Report no. 406, Texas A \& M University, College Station, 618 pp., 2011.

Nunes, J. P., Seixas, J., and Pacheco, N. R.: Vulnerability of water resources, vegetation productivity and soil erosion to climate change in Mediterranean watersheds, Hydrol. Process., 22, 3115-3134, 2008.

O’Neal, M. R., Nearing, M. A., Vining, R. C., Southworth, J., and Pfeifer, R. A.: Climate change impacts on soil erosion in Midwest United States with changes in crop management, Catena, 61, 165-184, 2005.

Osborn, T. J. and Jones, P. D.: The CRUTEM4 land-surface air temperature data set: construction, previous versions and dissemination via Google Earth, Earth Syst. Sci. Data, 6, 61-68, doi:10.5194/essd-6-61-2014, 2014.

Ouillon, S.: Erosion and sediment transport: width and stakes, La Houille Blanche, 53, 52-58, 1998.

Poesen, J., Nachtergaele, J., Verstraeten, G., and Valentin, C.: Gully erosion and environmental change: importance and research needs, Catena, 50, 91-133, 2003.

Pruski, F. F. and Nearing, M. A.: Climate-induced changes in erosion during the 21 st century for eight U.S. locations, Water Resour. Res., 38, 1298, doi:10.1029/2001WR000493, 2002.

Remini, B., Leduc, C., and Hallouche, W.: Evolution des grands barrages en régions arides: quelques exemples algériens, Sécheresse, 20, 96-103, 2009.

Riebe, C. S., Kirchner, J. W., Granger, D. E., and Finkel, R. C.: Minimal climatic control on erosion rates in the Sierra Nevada, California, Geology, 29, 447-450, 2001.

Sari, A.: Hydrologie de surface, cours d'initiation, Editions Distribution Houma, Houma, Alger, 155 pp., 2009. 
Searcy, J. K. and Hardison, C. H.: Double-mass curves, USGS Water-Supply Paper 1541-B, USGS, Washington, D.C., 1960.

Sen, P. K.: Estimates of regression coefficients based on Kendall's tau, J. Am. Stat. Assoc., 63, 1379-1389, 1968.

Shrestha, B., Babel, M. S., Maskey, S., van Griensven, A., Uhlenbrook, S., Green, A., and Akkharath, I.: Impact of climate change on sediment yield in the Mekong River basin: a case study of the Nam Ou basin, Lao PDR, Hydrol. Earth Syst. Sci., 17, 1-20, doi:10.5194/hess-17-1-2013, 2013.

Stahl, K., Hisdal, H., Hannaford, J., Tallaksen, L. M., van Lanen, H. A. J., Sauquet, E., Demuth, S., Fendekova, M., and Jódar, J.: Streamflow trends in Europe: evidence from a dataset of nearnatural catchments, Hydrol. Earth Syst. Sci., 14, 2367-2382, doi:10.5194/hess-14-2367-2010, 2010.

Summerfield, M. A. and Hulton, N. J.: Natural controls of fluvial denudation rates in major world drainage basins, J. Geophys. Res., 99, 13871-13883, 1994.

Syvitski, J. P. M.: Supply and flux of sediment along hydrological pathways: research for the $21^{\text {st }}$ century, Global Planet. Change, 39, 1-11, 2003.

Syvitski, J. P. M. and Milliman, J. D.: Geology, geography, and humans battle for dominance over the delivery of fluvial sediment to the coastal ocean, J. Geol., 115, 1-19, 2007.

Taabni, M. and El Jihad, M. D.: Eau et changement climatique au Maghreb: quelles stratégies d'adaptation?, Les Cahiers d'OutreMer, 260, 493-518, 2012.

Taibi, S., Meddi, M., Mahé, G., and Assani, A.: Variability of annual and extreme rainfall over Northern Algeria and relationship with teleconnections patterns, Proc. of the Mediterranean meeting on "Monitoring, modeling and early warning of extreme events triggered by heavy rainfalls", 26-28 June 2004, Univ. of Calabria, Cosenza, Italy, 2014.

Tebbi, F. Z., Dridi, H., and Morris, G. L.: Optimization of cumulative trapped sediment curve for an arid zone reservoir: Foum El Kherza (Biskra, Algeria), Hydrolog. Sci. J., 57, 1368-1377, 2012.

Temme, A. J. A. M. and Veldkamp, A.: Multi-process Late Quaternary landscape evolution modelling reveals lags in climate response over small spatial scales, Earth Surf. Proc. Land., 34, 573-589, 2009.

Tecsult International: Etude de la protection des bassins versants de l'ensemble des barrages en études d'avant projet détaillé (lots no. 1 à 4) et des bassins versants des barrages en exploitation (lots no. 5 et 6), Phase I description du milieu, lot no. 5: barrages Gargar et S. M. Ben-Aouda, Ministère des Ressources en Eau, Algérie, 2004.

Tockner, K. and Stanford, J. A.: Riverine flood plains: present state and future trends, Environ. Conserv., 29, 308-330, 2002.

Touaibia, B.: Problématique de l'érosion et du transport solide en Algérie septentrionnale, Sécheresse, 21, 1-6, 2010.
Touat, S.: Contrôle de la représentativité de l'échantillon des transports solides en suspension, Revue Eaux et Sols d'Algérie, 3, 48-54, 1989.

Tramblay, Y., El Adlouni, S., and Servat, E.: Trends and variability in extreme precipitation indices over Maghreb countries, Nat. Hazards Earth Syst. Sci., 13, 3235-3248, doi:10.5194/nhess-133235-2013, 2013.

Tucker, G. E. and Slingerland, R.: Drainage basin responses to climate change, Water Resour. Res., 33, 2031-2047, 1997.

Vanmaercke, M., Poersen, J., Broeckx, J., and Nyssen, J.: Sediment yield in Africa, Earth-Sci. Rev., 136, 350-368, 2014.

Vinh, V. D., Ouillon, S., Thanh, T. D., and Chu, L. V.: Impact of the Hoa Binh dam (Vietnam) on water and sediment budgets in the Red River basin and delta, Hydrol. Earth Syst. Sci., 18, 39874005, doi:10.5194/hess-18-3987-2014, 2014.

Vörösmarty, C. J., Meybeck, M., Fekete, B., Sharma, K., Green, P., and Syvitski, J. P. M.: Anthropogenic sediment retention: major global impact from registered river impoundments, Global Planet. Change, 39, 169-190, 2003.

Walling, D. E.: Assessing the accuracy of suspended sediment rating curves for a small basin, Water Resour. Res., 13, 531-538, 1977a.

Walling, D. E.: The response of sediment yields to environmental change, IAHS Publ. 245, in: Human impact on erosion and sedimentation, edited by: Walling, D. E. and Probst, J. L., IAHS Press, Wallingford, UK, 77-89, 1977b.

Walling, D. E.: Human impact on land-ocean sediment transfer by the world's rivers, Geomorphology, 79, 192-216, 2006.

Walling, D. E.: The impact of Global Change on Erosion and Sediment Transport by Rivers: Current progress and Future Challenges, The United Nations World Water Development Report 3, UNESCO, Paris, p. 26, 2009.

Walling, D. E. and Fang, D.: Recent trends in the suspended sediment loads of the world's rivers, Global Planet. Change, 39, 111126, 2003.

Wang, H., Yang, Z., Saito, Y., Liu, J., and Sun, X.: Interannual and seasonal variation of the Huanghe (Yellow River) water discharge over the past 50 years: connections to impacts from ENSO events and dams, Global Planet. Change, 50, 212-225, 2006.

Wang, H. J., Yang, Z. S., Saito, Y., Liu, J. P., Sun, X. X., and Wang, Y.: Stepwise decreases of the Huanghe (Yellow River) sediment load (1950-2005): Impacts of climate change and human activities, Global Planet. Change, 57, 331-354, 2007.

Ward, P. J., Eisner, S., Flörke, M., Dettinger, M. D., and Kummu, M.: Annual flood sensitivities to El Niño-Southern Oscillation at the global scale, Hydrol. Earth Syst. Sci., 18, 47-66, doi:10.5194/hess-18-47-2014, 2014.

Ziegler, A. D., Sheffield, J., Maurer, E. P., Nijssen, B., Wood, E. F., and Lettenmaier, D. P.: Detection of intensification in global- and continental-scale hydrological cycles: Temporal scale of evaluation, J. Climate, 16, 535-547, 2003. 